Check for updates

Cite this: RSC Adv., 2019, 9, 5402

\title{
Nitrogen oxide removal by non-thermal plasma for marine diesel engines
}

\author{
Zongyu Wang, ${ }^{a}$ Hailang Kuang, ${ }^{a}$ Jifeng Zhang, ${ }^{\text {ab }}$ Lilin $\mathrm{Chu}^{\mathrm{a}}$ and Yulong $\mathrm{Ji}$ (D) *a
}

The transportation industry plays an important role in the world economy. Diesel engines are still widely used as the main power generator for trucks, heavy machinery and ships. Removal technology for nitrogen oxides in diesel exhaust are of great concern. In this paper, a gas supply system for simulating the marine diesel engine exhaust is set up. An experimental study on exhaust denitration is carried out by using a dielectric barrier discharge (DBD) reactor to generate non-thermal plasma (NTP). The power efficiency and the denitration efficiency of different gas components by NTP are discussed. The exhaust gas reaction mechanism is analyzed. The application prospects of NTP are explored in the field of diesel exhaust treatment. The experimental results show that the power efficiency and energy density (ED) increase with the input voltage for this system, and the power efficiency is above $80 \%$ when the input voltage is higher than $60 \mathrm{~V}$. The removal efficiency of NO is close to $100 \%$ by NTP in the NO/N $\mathrm{N}_{2}$ system. For the $\mathrm{NO} / \mathrm{O}_{2} / \mathrm{N}_{2}$ system, the critical oxygen concentration (COC) increases with $\mathrm{NO}$ concentration. The $\mathrm{O}_{2}$ concentration plays a decisive role in the denitration performance of the NTP. $\mathrm{H}_{2} \mathrm{O}$ contributes to the oxidative removal of $\mathrm{NO}$, and $\mathrm{NH}_{3}$ improves the removal efficiency at low $\mathrm{ED}$ while slightly reducing the denitration performance at high ED. $\mathrm{CO}_{2}$ has little effect on NTP denitration performance, but as the ED increases, the generated $\mathrm{CO}$ gradually increases. When simulating typical diesel engine exhaust conditions, the removal efficiency increases first and then decreases with the increase of ED in the $\mathrm{NO} / \mathrm{O}_{2} / \mathrm{CO}_{2} / \mathrm{H}_{2} \mathrm{O} / \mathrm{N}_{2}$ system. After adding $\mathrm{NH}_{3}$, the removal efficiency of $\mathrm{NO}_{x}$ reaches up to $40.6 \%$. It is necessary to add reducing gas, or to combine the NTP technology with other post treatment technologies such as SCR catalysts or wet scrubbing, to further increase the NTP denitration efficiency.

Received 7th November 2018 Accepted 2nd February 2019

DOI: $10.1039 / c 8 \mathrm{ra09217f}$

rsc.li/rsc-advances plasma, thermal equilibrium plasma, and non-thermal equilibrium plasma depending on the temperature of the particles. It is used in a variety of fields such as welding and cutting, ${ }^{4}$ surface modification of materials, ${ }^{5-7}$ and the removal of contaminants. ${ }^{8-10}$ At present, the research on non-thermal equilibrium plasma (NTP) is the most extensive. The methods for generating NTP mainly include electron beam method, ${ }^{9,11,12}$ microwave irradiation method, ${ }^{5-7,13,14}$ high voltage discharge method (including DC, AC and pulse power), ${ }^{2,15-17}$ etc. The method of pulse power combined with the dielectric barrier discharge (DBD) reactor to generate NTP has many advantages, such as higher power efficiency, uniform and silent discharge. ${ }^{18-21}$ So it receives more attention. NTP used for exhaust post-treatment began in the 1970s and is one of the hotspots. It is almost no secondary pollution and has a good application prospect.

There are two ways for NTP to remove NO. One is to form $\mathrm{N}_{2}$ and $\mathrm{O}_{2}$ by reduction, and the other is to form higher valence oxides by oxidation, such as $\mathrm{NO}_{2}, \mathrm{~N}_{2} \mathrm{O}_{5}$, etc. $^{12,22}$ Moreover, diesel exhaust contains a large amount of $\mathrm{N}_{2}(\approx 76 \%)$ and $\mathrm{O}_{2}$ $(\approx 14 \%),{ }^{23}$ and because the dissociation energy of $\mathrm{O}_{2}(5.2 \mathrm{eV}$ mol $\left.^{-1}\right)$ is smaller than $\mathrm{N}_{2}\left(9.8 \mathrm{eV} \mathrm{mol}^{-1}\right),{ }^{24} \mathrm{O}_{2}$ will be converted to stronger oxidizing substance such as oxygen radical $(\cdot \mathrm{O})$ and $\mathrm{O}_{3}$. These reasons make it more unfavorable to remove NO by
${ }^{a}$ Marine Engineering College, Dalian Maritime University, Dalian 116026, China. E-mail:wangzongyu09@163.com; jiyulong@dlmu.edu.cn; Tel: +86-0411-84724306

${ }^{b}$ Yangtze Delta Region Institute of Tsinghua University, Zhejiang, Jiaxing 314006, China 
the reduction route. NO which is difficult to remove in the exhaust gas is converted into other components, whether it is reduced to $\mathrm{N}_{2}$ or oxidized to high-valent nitrogen oxides, the denitration efficiency can be increased. We mainly focus on the denitration efficiency, and the exact percentage of NO reduction to $\mathrm{N}_{2}$ will no long be discussed in the paper.

Zhang and $\mathrm{Zhou}^{25,26}$ used pulse corona discharge plasma combined with lye absorption for desulfurization and denitration simultaneously. They studied NO oxidation efficiency and removal efficiency by parameters such as gas flow, discharge current, $\mathrm{NO}$ concentration and $\mathrm{SO}_{2}$ concentration. But they did not consider the effect of $\mathrm{O}_{2}$ concentration on NTP $\mathrm{NO}_{x}$ removal efficiency. Some studies ${ }^{24,27}$ show that with the increasing of $\mathrm{O}_{2}$ concentration, the removal efficiency of $\mathrm{NO}_{x}$ gradually decreases, and there is so called critical oxygen concentration (COC) at which the $\mathrm{NO}_{x}$ removal efficiency is zero, which means the reduction rate of converting $\mathrm{NO}_{x}$ to $\mathrm{N}_{2}$ and $\mathrm{O}_{2}$ is equal to the oxidation rate of converting $\mathrm{N}_{2}$ to $\mathrm{NO}_{x}$. And critical $\mathrm{O}_{2}$ concentration may change with initial $\mathrm{NO}$ concentration. Mok et al. ${ }^{\mathbf{1 6}}$ used pulsed corona discharge NTP to study the effect of $\mathrm{O}_{2}$ concentration, humidity and peak voltage on the removal efficiency, but the NO concentration was only $210 \mathrm{ppm}\left(1 \mathrm{ppm}=1 \mu \mathrm{L} \mathrm{L}^{-1}\right)$ in their experiment. Zhao et al. ${ }^{\mathbf{2 4}}$ studied the removal efficiency of corona discharge NTP at different $\mathrm{O}_{2}$ concentrations (0-13.6\%), but the NO concentration in this study was only $437 \mathrm{ppm}$, which was much smaller than that of typical real ship diesel exhaust. What's more, both $\mathrm{H}_{2} \mathrm{O}$ and $\mathrm{CO}_{2}$ are inevitable components in diesel exhaust. These components may affect the NTP denitration reaction, while $\mathrm{ZhaO}^{24}$ and Aritoshi ${ }^{27}$ did not consider the effect of $\mathrm{H}_{2} \mathrm{O}$ on NTP denitration performance. And most researchers have not considered the effect of $\mathrm{CO}_{2}$ on NTP denitration performance. Also, the denitration mechanism of NTP is not the same under different gas composition, and still needs further exploration. In addition, because the exhaust gas temperature changes with the diesel engine power, and engine exhaust gas generally contains $\mathrm{SO}_{2}$ (the concentration varies with the sulfur content of the fuel used, such as the concentration of $\mathrm{SO}_{2}$ in the exhaust gas is about $600 \mu \mathrm{L} \mathrm{L}^{-1}$ for marine large low-speed two-stroke diesel engine when using heavy fuel oil of $3.5 \%$ sulfur content ${ }^{23}$ ), both temperature and $\mathrm{SO}_{2}$ will have a certain impact on the NTP denitration efficiency. Chmielewski et al. ${ }^{12}$ studied the effects of different temperatures $\left(70{ }^{\circ} \mathrm{C}\right.$ and $\left.90{ }^{\circ} \mathrm{C}\right)$ and the $\mathrm{SO}_{2}$ concentration $\left(0-2000 \mu \mathrm{L} \mathrm{L}{ }^{-1}\right)$ on the NTP denitration efficiency. Their experimental results show that the plasma denitration efficiency will increase with the temperature, so as the $\mathrm{SO}_{2}$ concentration. We want to investigate the NTP denitration efficiency in the poor cases and the application prospect of NTP. Therefore, the influence of temperature and $\mathrm{SO}_{2}$ concentration on the NTP denitration efficiency is not considered in this paper. All experiments are carried out at room temperature of $25{ }^{\circ} \mathrm{C}$ and the concentration of $\mathrm{SO}_{2}$ is zero.

In summary, in order to study the effects of energy density, different initial $\mathrm{NO}, \mathrm{O}_{2}, \mathrm{NH}_{3}, \mathrm{H}_{2} \mathrm{O}$ and $\mathrm{CO}_{2}$ on the NTP denitration performance, a simulating diesel exhaust supply system was set up in this paper. A coaxial cylindrical DBD reactor was designed and fabricated with quartz glass. Non-thermal plasma was generated by pulsed power. $\mathrm{NO}_{x}$ removal mechanism was proposed and analyzed by experimental results. The application prospects of NTP were explored in the field of diesel exhaust treatment.

\section{Approach}

The exhaust composition of a typical large-scale low-speed twostroke diesel engine is shown in Table 1 . NO accounts for more than $90 \%$ of $\mathrm{NO}_{x}$ in the diesel exhaust, the rest mainly being $\mathrm{NO}_{2}$, and NO is relatively more difficult to remove. Therefore, this paper mainly focuses on the removal of NO. The concentration of NO in the diesel exhaust will change with the engine load, and generally does not exceed $1500 \mu \mathrm{L} \mathrm{L}^{-1}$. Therefore, three NO concentrations indicating the emissions at different engine loads are studied in the paper, including the low NO concentration (500 $\left.\mu \mathrm{L} \mathrm{L}^{-1}\right)$, the medium NO concentration $\left(1000 \mu \mathrm{L} \mathrm{L}^{-1}\right)$ and the high NO concentration $\left(1500 \mu \mathrm{L} \mathrm{L}^{-1}\right)$. When $\mathrm{NH}_{3}$ is needed, it is added at an ammonia-nitrogen ratio of 1 . The highest $\mathrm{O}_{2}$ concentration in engine exhaust gas is $14 \%$, and in order to study the changes of critical $\mathrm{O}_{2}$ concentrations with initial $\mathrm{NO}$ concentrations, the final selected $\mathrm{O}_{2}$ concentrations are $1 \%, 5 \%$, $8 \%, 10 \%$ and $14 \%$, respectively. $\mathrm{H}_{2} \mathrm{O}$ can generate a variety of strong oxidizing free radicals in NTP, including $\cdot \mathrm{HO}_{2}, \cdot \mathrm{OH}$ and $\mathrm{H}_{2} \mathrm{O}_{2}$. They will have a certain influence on the NTP denitration performance. Therefore, three groups of experiments with $\mathrm{H}_{2} \mathrm{O}$ concentrations of $0 \%, 3.5 \%$ and $5.1 \%$ are selected for comparison. Because the experimental results show that $\mathrm{CO}_{2}$ has little effect on the NTP denitration performance, $0 \%$ and $4.5 \% \mathrm{CO}_{2}$ concentration are selected for comparative analysis in this paper. Considering the different components in the diesel exhaust and the performance of the power source, the gas components of each experiment vary from simple to complex. Because $\mathrm{N}_{2}$ accounts for the largest proportion in the exhaust gas, it is used as carrier gas in our experiments. In addition, $\mathrm{O}_{2}$ accounts for the second proportion in the exhaust gas and has the fundamental effect on the NTP denitration performance, the experiments of single component gas in NTP are carried both in $\mathrm{NO} / \mathrm{N}_{2}$ system and $\mathrm{O}_{2} / \mathrm{N}_{2}$ system. Other gases do not seem to be major players in this case and given the length of the article, they are not included in this paper so far. The following research is carried out:

(1) The denitration performance of NTP is strongly related to the energy density in DBD, and the output efficiency of the power source is an important factor to be considered in future industrial applications. Therefore, the energy density and power supply efficiency varying with different input voltages and currents were studied firstly under a typical diesel exhaust condition, i.e., $1500 \mu \mathrm{L} \mathrm{L}^{-1} \mathrm{NO}+14 \% \mathrm{O}_{2}+5.1 \% \mathrm{H}_{2} \mathrm{O}+4.5 \% \mathrm{CO}_{2}$ $+76.2 \% \mathrm{~N}_{2}$. Secondly, to understand the removal mechanism of the single-component NO exhaust, and the effect of the NO concentration on the power supply characteristics under a specific ideal condition, we carried out a group of experiments

Table 1 Low-speed two-stroke diesel engine exhaust composition (volume fraction) ${ }^{23}$

$\begin{array}{llllll}\text { Components } & \mathrm{N}_{2}(\%) & \mathrm{O}_{2}(\%) & \mathrm{CO}_{2}(\%) & \mathrm{H}_{2} \mathrm{O}(\%) & \mathrm{NO}_{x}\left(\mu \mathrm{L} \mathrm{L}^{-1}\right) \\ \text { Volume fraction } & 76.2 & 14 & 4.5 & 5.1 & 1500\end{array}$


in $\mathrm{NO} / \mathrm{N}_{2}$ system, where initial NO concentrations were $500 \mu \mathrm{L}$ $\mathrm{L}^{-1}, 1000 \mu \mathrm{L} \mathrm{L}^{-1}$ and $1500 \mu \mathrm{L} \mathrm{L}^{-1}$, respectively.

(2) Since $\mathrm{N}_{2}$ and $\mathrm{O}_{2}$ are the main components of diesel exhaust, $\mathrm{O}_{2}$ will be converted to a large amount of oxygen active particles with strong oxidative in NTP system, and $\mathrm{N}_{2}$ will also be converted to nitrogen active particles. These active particles will recombine to a certain concentration of $\mathrm{NO}_{x}$, which will partially offset the $\mathrm{NO}_{x}$ removal effect of NTP. Therefore, the oxidative formation of $\mathrm{NO}_{x}$ at different energy densities was investigated in $\mathrm{O}_{2} / \mathrm{N}_{2}$ system with the $\mathrm{O}_{2}$ concentration of $1 \%$, $5 \%, 10 \%$ and $14 \%$, respectively.

(3) It is expected that $\mathrm{NO}$ is converted to $\mathrm{N}_{2}$ and $\mathrm{O}_{2}$ through the reduction route. And the mechanism of NO removal by reduction way needs further study. Therefore, we carried out these experiments in $\mathrm{NO} / \mathrm{N}_{2}$ system with the initial $\mathrm{NO}$ concentrations of $500 \mu \mathrm{L} \mathrm{L}^{-1}, 1000 \mu \mathrm{L} \mathrm{L}^{-1}$ and $1500 \mu \mathrm{L} \mathrm{L}^{-1}$, respectively.

(4) As mentioned above, there is a critical oxygen concentration (COC) that makes the $\mathrm{NO}_{x}$ removal efficiency zero. When the $\mathrm{O}_{2}$ concentration is higher than the COC, the NTP will not have denitration ability with the ED increasing. It even leads to the increase of the $\mathrm{NO}_{x}$. While when the $\mathrm{O}_{2}$ concentration is lower than the COC, the removal efficiency increases with the ED. What's more, the COC is also related to the initial NO concentration. Therefore, we investigated the range of the COC at initial NO concentrations of $500 \mu \mathrm{L} \mathrm{L}^{-1}, 1000 \mu \mathrm{L} \mathrm{L}^{-1}$ and 1500 $\mu \mathrm{L} \mathrm{L}^{-1}$, respectively.

(5) $\mathrm{NH}_{3}$ is often used as reducing agent in traditional selective catalytic reduction (SCR) denitration, while the NTP denitration performance and mechanism are not well understood when $\mathrm{NH}_{3}$ exists. To this end, the effect of $\mathrm{NH}_{3}$ in $\mathrm{NO} / \mathrm{O}_{2} / \mathrm{N}_{2}$ system was studied at $\mathrm{O}_{2}$ concentrations of $1 \%, 5 \%, 8 \%, 10 \%$ and $14 \%$ with initial NO concentrations of $500 \mu \mathrm{L} \mathrm{L}^{-1}, 1000 \mu \mathrm{L}$ $\mathrm{L}^{-1}$ and $1500 \mu \mathrm{L} \mathrm{L}^{-1}$, respectively.
(6) $\mathrm{H}_{2} \mathrm{O}$ is an inevitable component in diesel exhaust. $\mathrm{H}_{2} \mathrm{O}$ will generate strong oxidizing hydroxyl radical $(\cdot \mathrm{OH})$ by the action of NTP, which will further inhibit NO reduction removal. When $\mathrm{NH}_{3}$ is added to the system, the NO removal reactions will be more complicated. In this paper, the NTP denitration performance was studied in $\mathrm{NO} / \mathrm{O}_{2} / \mathrm{H}_{2} \mathrm{O} / \mathrm{N}_{2}$ system with initial NO concentrations of $500 \mu \mathrm{L} \mathrm{L}^{-1}, 1000 \mu \mathrm{L} \mathrm{L}^{-1}$ and $1500 \mu \mathrm{L} \mathrm{L}^{-1}$, $\mathrm{O}_{2}$ concentration of $14 \%$ and $\mathrm{H}_{2} \mathrm{O}$ concentrations of $0 \%, 3.5 \%$ and $5.1 \%$, respectively. These results were also compared with that when $\mathrm{NH}_{3}$ was added.

(7) $\mathrm{CO}_{2}$ is the fourth major component of diesel exhaust. At present, most studies ignore the effect of $\mathrm{CO}_{2}$ on NTP denitration performance. However, $\mathrm{CO}_{2}$ may convert to $\mathrm{CO}$ in NTP, and $\mathrm{CO}$ has been used as the reducing agent for denitration in some reports. ${ }^{28-31}$ Therefore, in order to study the possible effects of $\mathrm{CO}_{2}$ on NTP denitration, we added $4.5 \% \mathrm{CO}_{2}$ in $\mathrm{NO} /$ $\mathrm{O}_{2} / \mathrm{H}_{2} \mathrm{O} / \mathrm{N}_{2}$ system with initial NO concentrations of $500 \mu \mathrm{L} \mathrm{L}^{-1}$, $1000 \mu \mathrm{L} \mathrm{L}^{-1}$ and $1500 \mu \mathrm{L} \mathrm{L}^{-1}, \mathrm{O}_{2}$ concentration of $14 \%$ and $\mathrm{H}_{2} \mathrm{O}$ concentration of $5.1 \%$, respectively. Then $\mathrm{NH}_{3}$ was added in $\mathrm{NO} / \mathrm{O}_{2} / \mathrm{H}_{2} \mathrm{O} / \mathrm{CO}_{2} / \mathrm{N}_{2}$ system to investigate the possible changes.

(8) Finally, based on the above experimental results, the NTP denitration mechanism of simulating diesel exhaust is proposed in the paper, and the application prospect of NTP denitration in the field of marine diesel exhaust is discussed.

\section{Experimental system and data processing}

\subsection{Experimental system}

The experimental system is shown in Fig. 1. It mainly includes gas supply unit, pulse plasma power unit, DBD reactor, flue gas analyzer (Testo350, Germany), and exhaust absorption device. The gas supply unit mainly includes gas cylinder, pressure reducing valve, mass flow controller (Beijing Sevenstar CS200A,

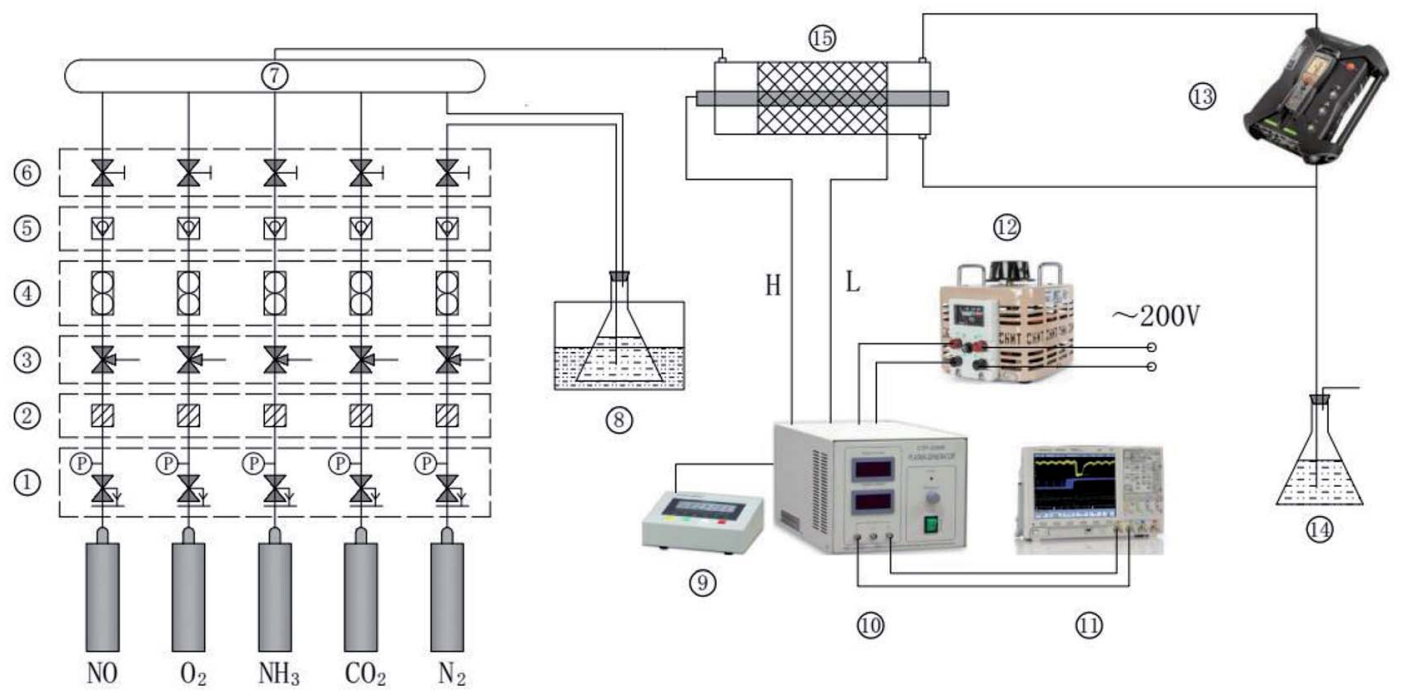

1. Pressure reducing valve 2. Filter 3. Three-way valve 4. Mass flow controller 5 . Check valve 6 . Stop valve 7. Mixing chamber 8. Water bath 9. Pulse modulator 10. Plasma power source 11. Digital oscilloscope 12. Voltage regulator 13. Flue gas analyzer 14. Exhaust gas absorption device 15. DBD reactor

Fig. 1 Experimental system of DBD denitration. 


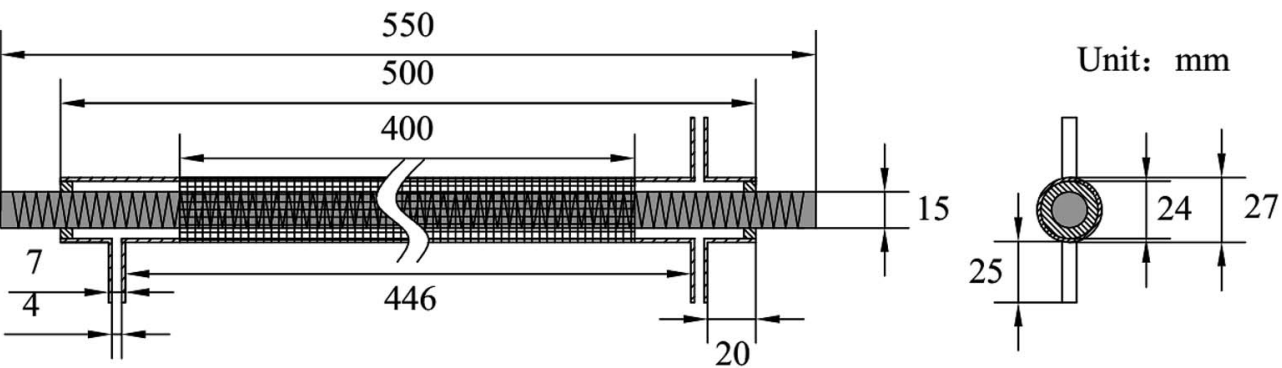

Fig. 2 Structure and dimensions of DBD reactor.

D, China), mixing chamber. The pulse plasma power unit mainly includes plasma power source (Nanjing Suman CTP2000K, China), pulse modulator (Nanjing Suman PC-07, China), voltage regulator (Zhejiang Chint TDGC2-1, China), digital oscilloscope (Agilent MSO7104B, USA). $\mathrm{N}_{2}, \mathrm{O}_{2}$ and $\mathrm{CO}_{2}$ are high-purity standard gas. $\mathrm{NO}$ is $10 \%$ standard gas with $\mathrm{N}_{2}$ as the carrier gas, and so as $\mathrm{NH}_{3} \cdot \mathrm{H}_{2} \mathrm{O}$ is added by the $\mathrm{N}_{2}$ bubbling method with constant temperature water bath. The DBD reactor is made of quartz glass. The structure and dimensions are shown in Fig. 2. The left end of the reactor is inlet, and the right end is outlet and detection port. The inner diameter of the reactor body is $24 \mathrm{~mm}$, and the outer diameter is $27 \mathrm{~mm}$. A copper rod is inserted in the reactor body as high-voltage electrode which is $550 \mathrm{~mm}$ long and $15 \mathrm{~mm}$ in diameter. The surface of the copper rod is machined with thread which is $2 \mathrm{~mm}$ in pitch and $1 \mathrm{~mm}$ in depth. The outer surface of the reactor is coated with 60 mesh copper net connected with the low voltage electrode of the power source. The discharge space is $4.5 \mathrm{~mm}$.

\subsection{Experimental method}

The total gas flow is kept constant at $2 \mathrm{~L} \mathrm{~min}^{-1}$ with $\mathrm{N}_{2}$ as carrier gas in all experiments. The concentrations of $\mathrm{N}_{2}, \mathrm{NO}, \mathrm{CO}_{2}, \mathrm{O}_{2}$, and $\mathrm{NH}_{3}$ in the DBD reactor are adjusted by the mass flow controllers. The $\mathrm{H}_{2} \mathrm{O}$ is added in by bubbling method, and its concentration is controlled by the temperature of the water bath. Before each group of experiments, the plasma power source is kept off and the initial gas concentration is adjusted to the demanded level according to the flue gas analyzer's measurement. Then the plasma power source is turned on to generate NTP in the DBD reactor. The output power of the power source is adjusted by input voltage and input current. And the concentrations of the DBD reactor outlet gas at different powers are monitored continuously. The input voltage of the plasma power source is controlled by the voltage regulator, and the input current is controlled by the frequency adjustment knob of the plasma power source. When the input voltage is constant, the input current can adjust to the maximum value by the frequency knob. It is also the maximum input power at the voltage, and the frequency of the output sine wave is generally $6-8 \mathrm{kHz}$.

The initial output of the plasma power source is sine waves with certain frequency, as shown in Fig. 3 . The sine waves with certain frequency can be modulated into pulse waves with

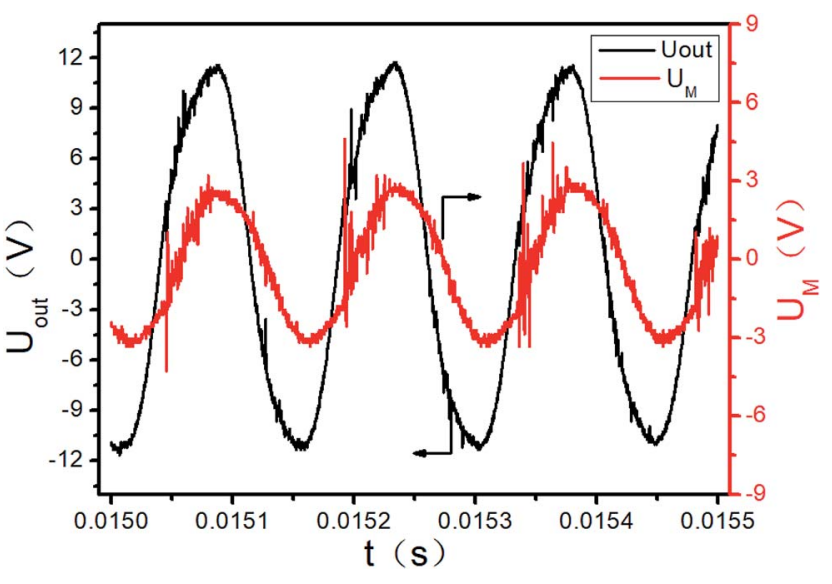

Fig. 3 Sine wave of the initial power output (partial).

different duty cycles and pulse frequencies by the pulse modulator, as shown in Fig. 4 . The attenuation ratio $K$ of output voltage $U_{\text {out }}$ is $1000: 1$ in Fig. 3 and 4, which means the true coordinate unit of $U_{\text {out }}$ is $\mathrm{kV}$ (in order to be consistent with the calculation process below, the unit of $U_{\text {out }}$ is still set as $V$ in the Fig. 3, 4 and 6). In all these experiments, the pulse frequency and the duty cycle are kept at $200 \mathrm{~Hz}$ and $50 \%$, respectively.

\subsection{Data processing}

The $\mathrm{NO}_{x}$ removal efficiency is calculated according to the imported and exported $\mathrm{NO}_{x}$ concentration of DBD recorded by

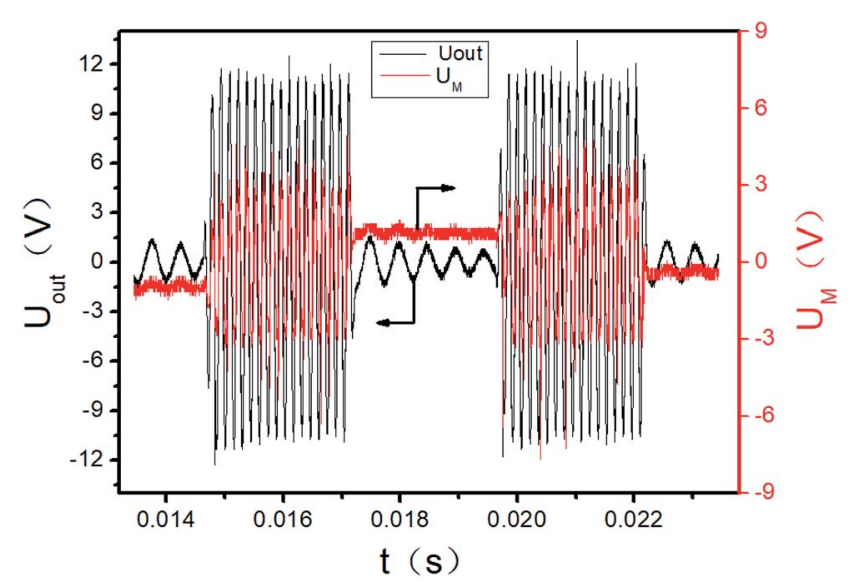

Fig. 4 Pulse signal of power output (2 cycles). 


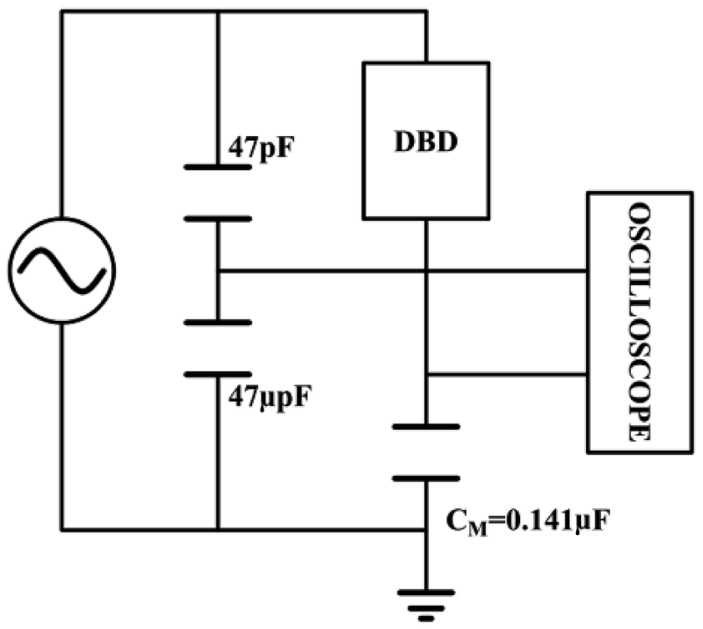

Fig. 5 Equivalent circuit diagram for discharging power by voltagecharge method.

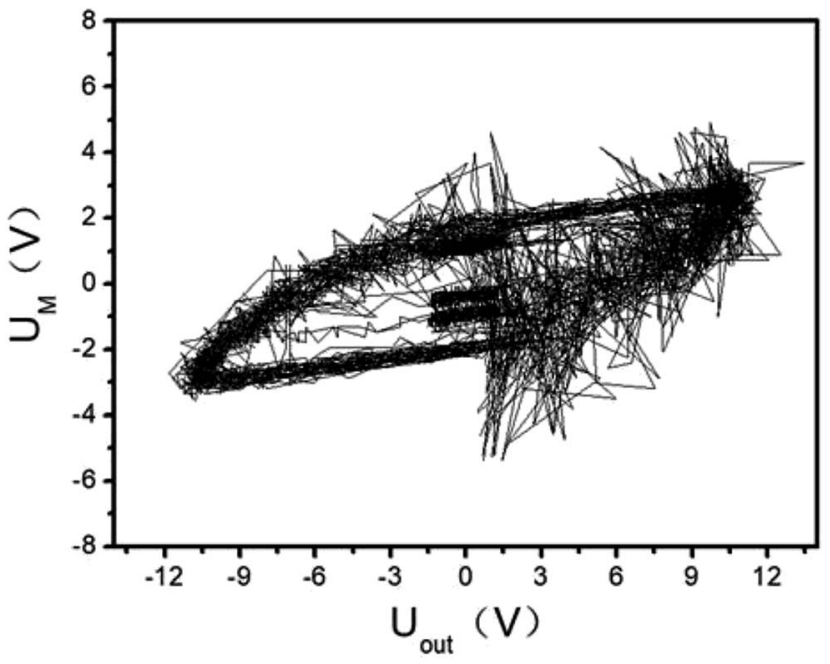

Fig. 6 Diagram of Lissajous integral area.

the flue gas analyzer. The input power of the power source is calculated according to the input voltage and current. The output power of the power source is calculated according to the output waveform of the power source recorded by the digital oscilloscope. The power efficiency and the energy density were calculated further.

The removal efficiency of $\mathrm{NO}_{x}$ is calculated by the following formula:

$$
\eta_{\mathrm{NO}_{x}}=\frac{C_{\text {in }}-C_{\text {out }}}{C_{\text {in }}} \times 100 \%
$$

Here $\eta_{\mathrm{NO}_{x}}$ is the removal efficiency of $\mathrm{NO}_{x}, \%$; $C_{\mathrm{in}}$ is the inlet $\mathrm{NO}_{x}$ concentration (the sum of $\mathrm{NO}$ and $\mathrm{NO}_{2}$ concentration), $\mu \mathrm{L}$ $\mathrm{L}^{-1}$; $C_{\text {out }}$ is the outlet $\mathrm{NO}_{x}$ concentration, $\mu \mathrm{L} \mathrm{L}^{-1}$.

The input power of the plasma power source is calculated as follows:

$$
P_{\text {in }}=U_{\text {in }} I_{\text {in }}
$$

Here $P_{\text {in }}$ is the input power of the plasma power source, $\mathrm{W} ; U_{\text {in }}$ is the input voltage of the power source, $\mathrm{V} ; I_{\mathrm{in}}$ is the input current of the power source, A.

The output power of the plasma power source is calculated by the voltage-electric charge Lissajous method. ${ }^{32-34}$ Its equivalent circuit is shown in Fig. 5. The measurement principle is that a $0.141 \mu \mathrm{F}$ capacitor $C_{\mathrm{M}}$ is connected in series with the lowvoltage end of the DBD reactor. The voltage $U_{\mathrm{M}}$ of the capacitor $C_{\mathrm{M}}$ is measured by the digital oscilloscope. The electric charge $Q$ of the DBD discharge is equal to the capacitor $C_{\mathrm{M}}$. The current flowing through the loop is calculated as:

$$
I_{\text {out }}=\frac{\mathrm{d} Q}{\mathrm{~d} t}=\frac{\mathrm{d}\left(C_{\mathrm{M}} U_{\mathrm{M}}\right)}{\mathrm{d} t}=\frac{C_{\mathrm{M}} \mathrm{d} U_{\mathrm{M}}}{\mathrm{d} t}
$$

The discharge power is defined as:

$$
P=\frac{1}{T} \int_{0}^{T} U_{\text {out }} I_{\text {out }} \mathrm{d} T=\frac{C_{\mathrm{M}}}{T} \int_{0}^{T} U_{\text {out }} \frac{\mathrm{d} U_{\mathrm{M}}}{\mathrm{d} t} \mathrm{~d} T=f C_{\mathrm{M}} \oint U_{\text {out }} \mathrm{d} U_{\mathrm{M}}
$$

The $U_{\mathrm{M}}$ and $U_{\text {out }}$ are measured by the digital oscilloscope. When the input voltage is $100 \mathrm{~V}$ and the input current is $0.8 \mathrm{~A}$, the curves of the high-voltage signal $U_{\text {out }}$ and $U_{\mathrm{M}}$ are shown in Fig. 4. The waveforms during $0.0150-0.0155$ seconds of Fig. 4 are shown in Fig. 3. The Lissajous figure is shown in Fig. 6 with $U_{\text {out }}$ as the $X$-axis and $U_{\mathrm{M}}$ as the $Y$-axis. The Lissajous figure area A of a single pulse period is calculated by integration tool of origin. The sensitivity of the oscilloscope in the $X$ and $Y$ directions is $K_{X}$ and $K_{Y}$, respectively. The output power by voltageelectric charge Lissajous method can be defined as:

$$
P_{\text {out }}=f K C_{\mathrm{M}} K_{X} K_{Y} A
$$

The power efficiency of NTP can be expressed as:

$$
\eta_{\mathrm{P}}=\frac{P_{\text {out }}}{P_{\text {in }}} \times 100 \%
$$

The output power of the plasma power source is equal to the power loaded in the DBD reactor. The energy density (ED) is usually used to represent the amount of energy that the DBD reactor acting on the flue gas. The calculation formula can be expressed as:

$$
\mathrm{ED}=\frac{60 \times P_{\text {out }}}{1000 \times Q_{\text {exhaust }}}
$$

Here ED is the energy density of the DBD reactor, $\mathrm{kJ} \mathrm{L}^{-1} ; P_{\text {out }}$ is the output power of the plasma power source, $\mathrm{W} ; Q_{\text {exhaust }}$ is the

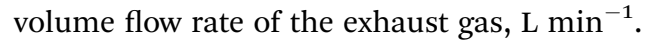

\section{Results and discussion}

\subsection{The changes of ED and power efficiency}

Gas breakdown will occur when the voltage between the two electrodes of the DBD reactor is higher than a certain value. The breakdown voltage is closely related to the discharge space. And it is also related to the gas composition and the ED in DBD 


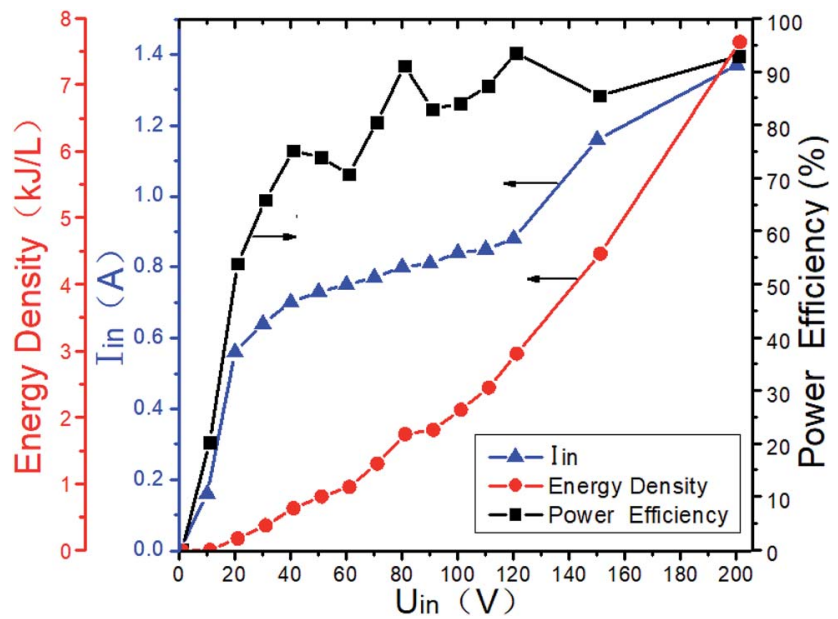

Fig. $7 \mathrm{ED}$ and power efficiency vary with input voltage at $1500 \mu \mathrm{L} \mathrm{L}^{-1}$ $\mathrm{NO}+14 \% \mathrm{O}_{2}+5.1 \% \mathrm{H}_{2} \mathrm{O}+4.5 \% \mathrm{CO}_{2}+76.2 \% \mathrm{~N}_{2}$.

reactor. When the typical marine diesel engine exhaust is simulated, that is, $1500 \mu \mathrm{L} \mathrm{L}^{-1} \mathrm{NO}+14 \% \mathrm{O}_{2}+5.1 \% \mathrm{H}_{2} \mathrm{O}+4.5 \%$ $\mathrm{CO}_{2}+76.2 \% \mathrm{~N}_{2}$, the changes of ED and power efficiency with input voltage are shown in Fig. 7. When the input voltage is low $(<20 \mathrm{~V})$, the discharge is extremely unstable, and the input current is also small, so as the output power and power efficiency. As the input voltage increases $(20-60 \mathrm{~V})$, the DBD discharge becomes more and more stable, and the input current also increases gradually, so as the ED and power efficiency. When the input voltage is higher than $60 \mathrm{~V}$, the input current and the ED gradually increases with the input voltage, and the power efficiency remains above 80\%. As shown in Fig. 8, the power efficiency varies with the input voltage in the $\mathrm{NO} / \mathrm{N}_{2}$ system, where $\mathrm{N}_{2}$ as the carrier gas and NO concentrations are $500 \mu \mathrm{L} \mathrm{L}^{-1}, 1000 \mu \mathrm{L} \mathrm{L}^{-1}$ and $1500 \mu \mathrm{L} \mathrm{L}^{-1}$, respectively. When the input voltage is lower than $20 \mathrm{~V}$, the power efficiency does not exceed $70 \%$, when the input voltage is higher than $60 \mathrm{~V}$, the power efficiency remains above $80 \%$. Compared with Fig. 7,

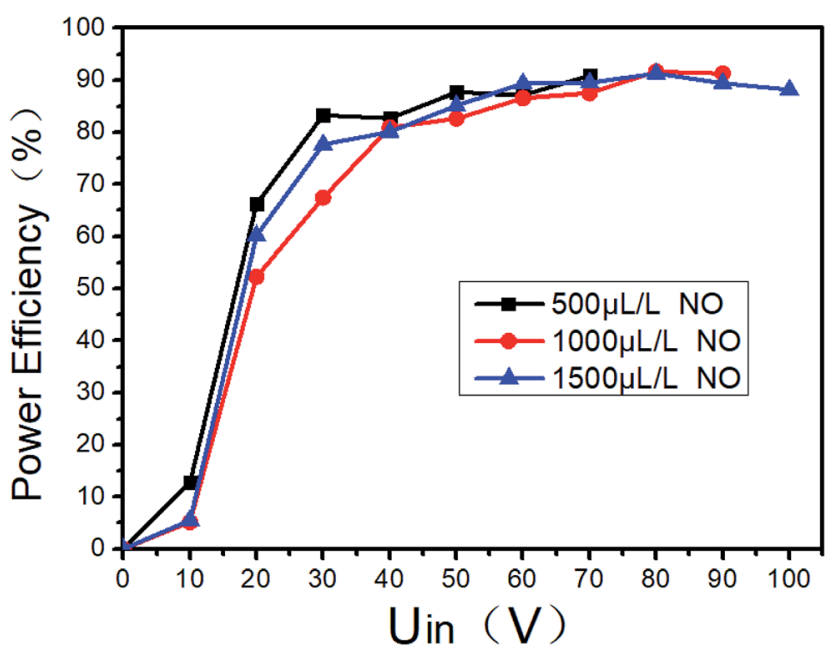

Fig. 8 Power output efficiency varies with input voltage at different $\mathrm{NO}$ concentrations. when the gas components are different at the same input voltage, the power efficiency is basically the same, indicating that the gas composition has little effect on the power efficiency.

In order to improve the power efficiency, the input voltage should be higher than $60 \mathrm{~V}$. If the system is used in practice, it is recommended that the input voltage be higher than $60 \mathrm{~V}$. However, when the system is scaled up, the optimal efficiency zone and the corresponding ED may be different, and should be determined in actual tests.

\subsection{Effect of NTP on single component $\mathrm{O}_{2}$}

As mentioned in the introduction, the main components in diesel exhaust are $\mathrm{N}_{2}$ and $\mathrm{O}_{2}$. They will have a great influence on NTP denitration. Therefore, we first study the effect of NTP in the $\mathrm{N}_{2} / \mathrm{O}_{2}$ system. The possible reactions may include R1-R18 (refer to the end of this section) at least. $\mathrm{N}_{2}$ and $\mathrm{O}_{2}$ will be converted into a variety of active particles in NTP. Herron ${ }^{35}$ and Fernandez's ${ }^{36}$ results show that only $\mathrm{N}\left({ }^{2} \mathrm{D}\right)$ and $\mathrm{N}\left({ }^{4} \mathrm{~S}\right)$ active particles participate in the NO generation process. Zhao, ${ }^{24}$ Herron, ${ }^{37}$ Atkinson ${ }^{38}$ and others have shown that mainly $\mathrm{O}\left({ }^{3} \mathrm{P}\right)$ and $\mathrm{O}\left({ }^{1} \mathrm{D}\right)$ active particles participate in the $\mathrm{NO}_{x}$ reaction process. Because of the high concentration of $\mathrm{N}_{2}$ and $\mathrm{O}_{2}$, and the reaction of R5 and R6 are faster, $\mathrm{O}\left({ }^{1} \mathrm{D}\right)$ will be quenched very quickly, and finally only $\mathrm{O}\left({ }^{3} \mathrm{P}\right)$ participates in the $\mathrm{NO}_{x}$ reaction process. The formations of active particles are shown as R1-R6. $\mathrm{N}\left({ }^{2} \mathrm{D}\right)$ and $\mathrm{N}\left({ }^{4} \mathrm{~S}\right)$ are no longer distinguished below, so as $\mathrm{O}\left({ }^{3} \mathrm{P}\right)$ and $\mathrm{O}\left({ }^{1} \mathrm{D}\right)$. They are denoted by $\cdot \mathrm{N}$ and $\cdot \mathrm{O}$, respectively.

The changes of DBD outlet gas concentration with ED in $\mathrm{O}_{2} /$ $\mathrm{N}_{2}$ system are shown in Fig. 9. Fig. 9(a) and (b) show the trend of $\mathrm{NO}$ and $\mathrm{NO}_{2}$ with $\mathrm{ED}$ at different $\mathrm{O}_{2}$ concentrations, respectively. From Fig. 9(a), it can be seen that NO will not be generated at low ED regardless of the $\mathrm{O}_{2}$ concentration. However as the $\mathrm{O}_{2}$ concentration and the ED increase, the NO concentration also increases. There will be no NO generated in the ED range of $0-7.6 \mathrm{~kJ} \mathrm{~L}^{-1}$ at $1 \% \mathrm{O}_{2}$ concentration. But when the $\mathrm{O}_{2}$ concentration is $14 \%$ and the SIE is $7.3 \mathrm{~kJ} \mathrm{~L}^{-1}$, the NO concentration is as high as $1018 \mu \mathrm{L} \mathrm{L}^{-1}$. The reactions $\mathrm{R} 7$ and R8 may take place in the process. From Fig. 9(b), it can be seen that $\mathrm{NO}_{2}$ is more easily generated at lower ED in the $\mathrm{N}_{2} / \mathrm{O}_{2}$ system. The concentration of $\mathrm{NO}_{2}$ increases first and then decreases with the increase of $\mathrm{O}_{2}$ concentration when the ED is higher than $2.1 \mathrm{~kJ}$ $\mathrm{L}^{-1}$, indicating that the excessive $\mathrm{O}_{2}$ will inhibit the generation of $\mathrm{NO}_{2}$. When $\mathrm{O}_{2}$ concentration is $5 \%$, it is most beneficial to the formation of $\mathrm{NO}_{2}$. The concentration of $\mathrm{NO}_{2}$ is up to $380 \mu \mathrm{L}$ $\mathrm{L}^{-1}$ when the $\mathrm{O}_{2}$ concentration is $5 \%$ and the $\mathrm{ED}$ is $0.9 \mathrm{~kJ} \mathrm{~L}^{-1}$.

Based on the above results, reactions R7-R16 may take place under our experimental condition. For R16, $\mathrm{O}_{3}$ will be formed by NTP in the presence of $\mathrm{O}_{2}$. Because $\mathrm{O}_{3}$ is more oxidative than $\mathrm{O}_{2}$, NO will be oxidized to higher valence oxides. The possible reactions are mainly $\mathrm{R} 16-\mathrm{R} 18 .{ }^{39}$ When the ED is $4 \mathrm{~kJ} \mathrm{~L}^{-1}$ and the $\mathrm{O}_{2}$ concentration is $14 \%$, the $\mathrm{NO}_{x}$ concentration is $750 \mu \mathrm{L} \mathrm{L}^{-1}$. According to the above experimental results, the generated $\mathrm{NO}_{x}$ concentration by NTP gradually increases with the $\mathrm{O}_{2}$ concentration and ED in $\mathrm{O}_{2} / \mathrm{N}_{2}$ system.

$$
\mathrm{e}+\mathrm{N}_{2} \rightarrow \mathrm{e}+\mathrm{N}\left({ }^{4} \mathrm{~S}\right)+\mathrm{N}\left({ }^{4} \mathrm{~S}\right)
$$



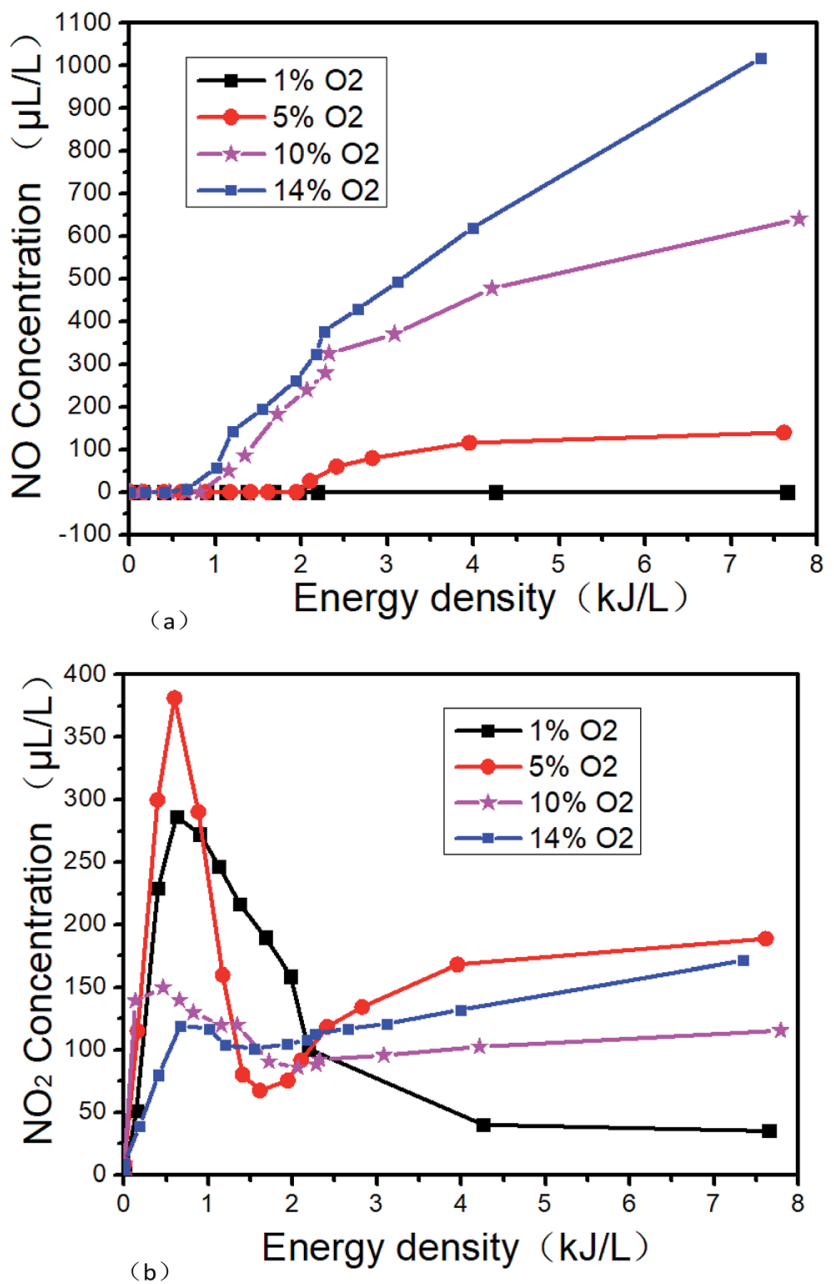

Fig. 9 Effect of NTP at different energy density in $\mathrm{O}_{2} / \mathrm{N}_{2}$ system. (a) $\mathrm{NO}$ varies with energy density, (b) $\mathrm{NO}_{2}$ varies with energy density.

$$
\begin{gathered}
\mathrm{e}+\mathrm{N}_{2} \rightarrow \mathrm{e}+\mathrm{N}\left({ }^{2} \mathrm{D}\right)+\mathrm{N}\left({ }^{2} \mathrm{D}\right) \\
\mathrm{e}+\mathrm{O}_{2} \rightarrow \mathrm{e}+\mathrm{O}\left({ }^{3} \mathrm{P}\right)+\mathrm{O}\left({ }^{3} \mathrm{P}\right) \\
\mathrm{e}+\mathrm{O}_{2} \rightarrow \mathrm{e}+\mathrm{O}\left({ }^{3} \mathrm{P}\right)+\mathrm{O}\left({ }^{1} \mathrm{D}\right) \\
\mathrm{O}\left({ }^{1} \mathrm{D}\right)+\mathrm{O}_{2} \rightarrow \mathrm{O}\left({ }^{3} \mathrm{P}\right)+\mathrm{O}_{2} \\
\mathrm{O}\left({ }^{1} \mathrm{D}\right)+\mathrm{N}_{2} \rightarrow \mathrm{O}\left({ }^{3} \mathrm{P}\right)+\mathrm{N}_{2} \\
\cdot \mathrm{N}+\mathrm{O}_{2} \rightarrow \mathrm{NO}+\cdot \mathrm{O} \\
\cdot \mathrm{N}+\cdot \mathrm{O} \rightarrow \mathrm{NO} \\
\cdot \mathrm{O}+\mathrm{NO} \rightarrow \mathrm{NO}{ }_{2} \\
\cdot \mathrm{O}+\mathrm{NO}_{2} \rightarrow \mathrm{NO}^{+\mathrm{O}_{2}} \\
\cdot \mathrm{N}+\mathrm{NO}_{2} \rightarrow \mathrm{N}_{2}+\mathrm{O}_{2} \\
\cdot \mathrm{N}+\mathrm{NO}^{\rightarrow} \mathrm{N}_{2}+\cdot \mathrm{O} \\
\cdot \mathrm{O}+\mathrm{NO}_{2} \rightarrow \mathrm{NO}_{3}
\end{gathered}
$$

$$
\begin{gathered}
\mathrm{e}+\mathrm{NO} \rightarrow \mathrm{e}+\cdot \mathrm{O}+\cdot \mathrm{N} \\
\mathrm{e}+\mathrm{NO}_{2} \rightarrow \mathrm{e}+\mathrm{NO}+\cdot \mathrm{O} \\
\mathrm{O}+\mathrm{O}_{2} \rightarrow \mathrm{O}_{3} \\
\mathrm{NO}+\mathrm{O}_{3} \rightarrow \mathrm{NO}_{2}+\mathrm{O}_{2} \\
\mathrm{NO}_{2}+\mathrm{O}_{3} \rightarrow \mathrm{NO}_{3}+\mathrm{O}_{2}
\end{gathered}
$$

\subsection{Effect of NTP on single component NO}

Fig. 10 shows the denitration performance of NTP in $\mathrm{NO} / \mathrm{N}_{2}$ system. Under this condition, $\mathrm{NO}$ is converted to $\mathrm{N}_{2}$ by the reduction way, and the reactions mainly are $\mathrm{R} 12$ and $\mathrm{R} 14 .^{40} \mathrm{It}$ can be seen from Fig. 10(a) that the removal efficiency slightly decreases with the increase of the NO concentration under the same ED. However, the NO is almost completely removed when the ED reaches a certain value. The removal efficiency increases with the ED when the NO concentration is constant. The
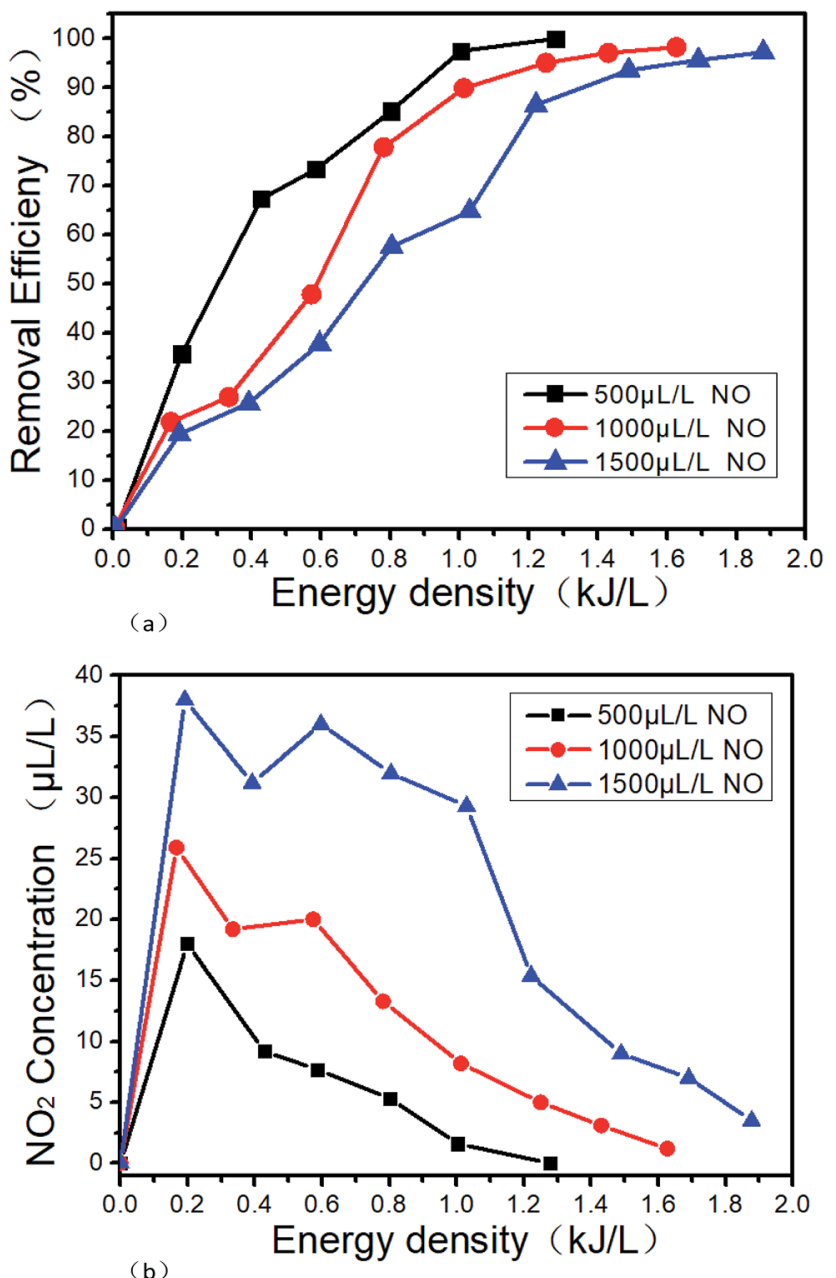

Fig. 10 Denitration performance of NTP at different energy densities in $\mathrm{NO} / \mathrm{N}_{2}$ system, (a) removal efficiency varies with the energy density, (b) $\mathrm{NO}_{2}$ varies with the energy density. 
removal efficiencies are all above $95 \%$ when the NO concentrations and the EDs are $500 \mu \mathrm{L} \mathrm{L}^{-1} 0.99 \mathrm{~kJ} \mathrm{~L}^{-1}, 1000 \mu \mathrm{L} \mathrm{L}^{-1} 1.26$ $\mathrm{kJ} \mathrm{L}^{-1}$ and $1500 \mu \mathrm{L} \mathrm{L}^{-1} 1.68 \mathrm{~kJ} \mathrm{~L}^{-1}$, respectively. The reason for the above experimental result is mainly that the collisions between molecules are more intense with the increase of ED, and R14 is more likely to take place. Also, the reaction R1 and $\mathrm{R} 2$ will produce more $\cdot \mathrm{N}$ active particles, and then the reaction R12 will increase the removal efficiency. $\mathrm{Sun}^{34}$ got the similar results with us when the NO concentration was $2000 \mu \mathrm{L} \mathrm{L}^{-1}$. It can be seen from Fig. 10(b) that while NO is removed by the reduction way, a small part of $\mathrm{NO}$ is also oxidized to $\mathrm{NO}_{2}$, which means that the reactions of R9 and R14 take place. And the higher the initial NO concentration, the more $\mathrm{NO}_{2}$ generates. However, with the increase of the ED, the concentration of $\mathrm{NO}_{2}$ increases first and then decreases. When the ED reaches a certain value, $\mathrm{NO}_{2}$ is completely removed mainly due to the reactions of R10, R11 and R15. Under the experimental condition, the highest removal efficiency of $99 \%$ is obtained in this paper.

Zhao's results ${ }^{24}$ show that with the increase of ED, the removal efficiency of $\mathrm{NO}_{x}$ will reach $98.5 \%$ wi0.5\%, and could not be further increased. It is mainly because that $\mathrm{N}_{2} \mathrm{O}$ which generated by the reaction of R19 is difficult to convert. When $\mathrm{NH}_{3}$ is added, R20 may also take place, but R21 is more difficult to take place. However, the speculation cannot be confirmed in this paper due to that the flue gas analyzer we use could not measure the $\mathrm{N}_{2} \mathrm{O}$ concentration.

Based on the above results, NO tends to reduce to $\mathrm{N}_{2}$ by NTP in $\mathrm{NO} / \mathrm{N}_{2}$ system, and the removal efficiency is higher than $95 \%$.

$$
\begin{gathered}
\mathrm{NO}+\cdot \mathrm{N} \rightarrow \mathrm{N}_{2} \mathrm{O} \\
\mathrm{NO}_{2}+\cdot \mathrm{NH}_{2} \rightarrow \mathrm{N}_{2} \mathrm{O}+\mathrm{H}_{2} \mathrm{O} \\
\mathrm{N}_{2} \mathrm{O}+\cdot \mathrm{O} \rightarrow 2 \mathrm{NO}
\end{gathered}
$$

\subsection{Effect of $\mathrm{O}_{2}$ on NTP denitration performance}

Tokunaga $^{41}$ and $\mathrm{ZhaO}^{24}$ believe that the removal efficiency of $\mathrm{NO}_{x}$ will decrease with the increase of $\mathrm{O}_{2}$ concentration, and there is a critical $\mathrm{O}_{2}$ concentration to make the $\mathrm{NO}_{x}$ removal efficiency zero. Tokunaga' results show that the critical $\mathrm{O}_{2}$ concentration is about $3.6 \%$ when the initial NO concentration is $500 \mu \mathrm{L} \mathrm{L}^{-1}$.41 Zhao's results show that the critical $\mathrm{O}_{2}$ concentration is about $2.5 \%$ when the initial NO concentration is $350 \mu \mathrm{L} \mathrm{L}^{-1} .^{24}$ The NO concentration of the typical marine diesel engine exhaust is generally much higher than $500 \mu \mathrm{L} \mathrm{L}^{-1}$. When the initial NO concentration is higher, the changes of the critical $\mathrm{O}_{2}$ concentration are not very clear. Based on this, the $\mathrm{NO}_{x}$ removal performance of NTP is studied when the initial NO concentrations, $\mathrm{O}_{2}$ concentrations and the EDs change. Fig. 11 shows the NTP denitration performance under different conditions of $\mathrm{NO}$ and $\mathrm{O}_{2}$. Since the remove rate is close to $100 \%$ at lower energy density when $\mathrm{O}_{2}$ concentration is zero, the experiments at higher energy densities are no longer performed.
It can be seen that the higher the NO concentration, the higher the removal efficiency at the same $\mathrm{O}_{2}$ concentration. The reason for this phenomenon is that the probability of NO collision with high-energy particles is higher in the reaction system with the increase of NO concentration. The greater the likelihood, the more NO will be removed by converting to $\mathrm{N}_{2}$. While it may be helpful to use the isotope labeling method to detect the migration of nitrogen atoms in NO to confirm the speculation, it is not included in this study due to experimental conditions.
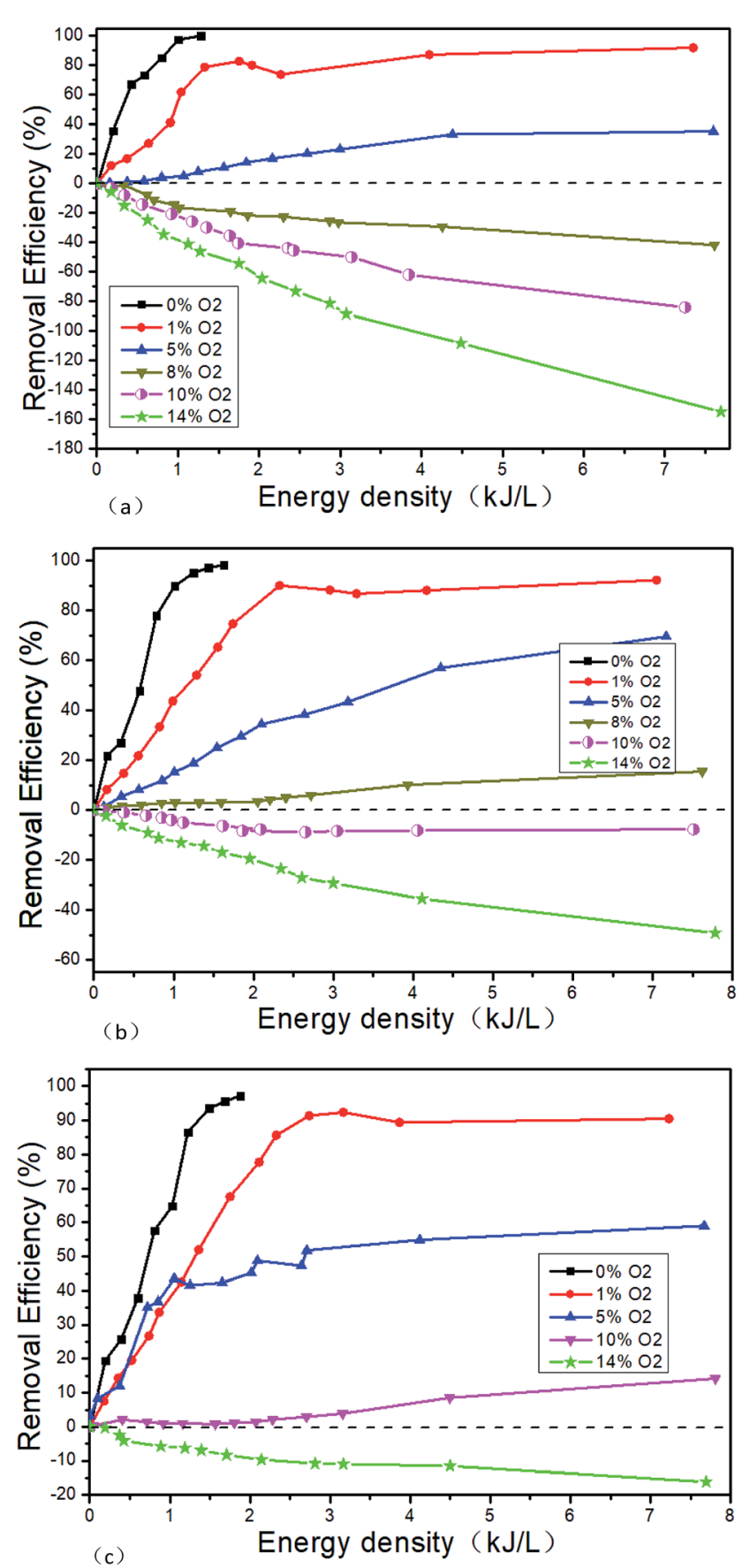

Fig. 11 Denitration performance of NTP in $\mathrm{NO} / \mathrm{O}_{2} / \mathrm{N}_{2}$ system, (a) 500 $\mu \mathrm{L} \mathrm{L}{ }^{-1} \mathrm{NO}+\mathrm{O}_{2}$, (b) $1000 \mu \mathrm{L} \mathrm{L}-1 \mathrm{NO}+\mathrm{O}_{2}$, (c) $1500 \mu \mathrm{LL}^{-1} \mathrm{NO}+\mathrm{O}_{2}$. 
Secondly, it can be seen that the removal efficiency decreases with the increase of $\mathrm{O}_{2}$ concentration when the initial NO concentration is constant. The removal efficiency is more than $90 \%$ at low $\mathrm{O}_{2}$ concentration (less than $1 \%$ ) when the ED is bigger enough. When the $\mathrm{O}_{2}$ concentration is more than $14 \%$, the removal efficiency is negative. And with the increase of the $\mathrm{ED}$, the removal efficiency is further reduced. The critical $\mathrm{O}_{2}$ concentration gradually increases with the initial NO concentration. The critical $\mathrm{O}_{2}$ concentration range is $5-8 \%$ when the initial NO concentration $500 \mu \mathrm{L} \mathrm{L}^{-1}$. Tokunaga ${ }^{41}$ believes that the critical $\mathrm{O}_{2}$ concentration is about $3.6 \%$ when the initial $\mathrm{O}_{2}$ concentration is $500 \mu \mathrm{L} \mathrm{L}^{-1}$. But our experimental results are not agreed with his. The possible reason is that the NTP generation methods are different. Tokunaga uses electron beam method and we use the DBD method. It is reported that the average free energy of electrons generated by the electron beam method is much higher than that of the DBD method. ${ }^{42}$ Therefore, more $\mathrm{N}_{2}$ which is difficult to excite is converted to $\cdot \mathrm{N}$ by the electron beam method. So the reactions of R1-R9 are easier by electron beam method even at lower $\mathrm{O}_{2}$ concentration. And then the chemical reaction direction is toward to $\mathrm{NO}_{x}$ generation.

The critical $\mathrm{O}_{2}$ concentration range is $5-8 \%, 8-10 \%$ and $10-$ $14 \%$ corresponding to the initial NO concentration $500 \mu \mathrm{L} \mathrm{L}^{-1}$, $1000 \mu \mathrm{L} \mathrm{L}^{-1}$ and $1500 \mu \mathrm{L} \mathrm{L}^{-1}$, respectively. The COC gradually increases with the initial NO concentration. The removal efficiency increases with the ED when the $\mathrm{O}_{2}$ concentration is lower than the COC, and decreases with the ED when the $\mathrm{O}_{2}$ concentration is higher than the COC.

\subsection{Effect of $\mathrm{NH}_{3}$ on NTP denitration performance}

$\mathrm{NH}_{3}$ is often used as reducing agent for the removal of $\mathrm{NO}_{x}$ in the conventional SCR method. At present, there are few studies on the $\mathrm{NO}_{x}$ removal by $\mathrm{NH}_{3}$ in NTP system, and the $\mathrm{NO}_{x}$ removal mechanism by NTP $+\mathrm{NH}_{3}$ is even more unclear. It is generally believed that the ammonia radical $\left(\cdot \mathrm{NH}_{2}\right)$ plays a major role in the $\mathrm{NO}_{x}$ removal in NTP system when $\mathrm{NH}_{3}$ is added. The reactions of the $\cdot \mathrm{NH}_{2}$ formation are $\mathrm{R} 22-\mathrm{R} 25$ (refer to the end of this section).

Fig. 12 shows the NTP denitration performance of $\mathrm{NH}_{3}$ under different conditions of $\mathrm{NO}$ and $\mathrm{O}_{2}$. Taking the initial NO concentration of $1000 \mu \mathrm{L} \mathrm{L}^{-1}$ as an example, it can be seen from the comparison with Fig. 11 that when the $\mathrm{O}_{2}$ concentration is $1 \%$ and the energy density is greater than $2.25 \mathrm{~kJ} \mathrm{~L}^{-1}$, the $\mathrm{NO}_{x}$ removal efficiency changes from $90 \%$ (Fig. 11(b) shown) to $80 \%$ (as shown in Fig. 12(b)) when $\mathrm{NH}_{3}$ is added. When the $\mathrm{O}_{2}$ concentration is greater than $10 \%$, the removal efficiency remains positive at low ED after adding $\mathrm{NH}_{3}$. But with the increase of the ED, the removal efficiency gradually decreases and eventually becomes negative. When the $\mathrm{O}_{2}$ concentration is $14 \%$ and the $\mathrm{ED}$ is $7.8 \mathrm{~kJ} \mathrm{~L}^{-1}$, the lowest removal efficiency changes from $-49.2 \%$ (as shown in Fig. 11(b)) to $-62.4 \%$ (as shown in Fig. 12(b)) after $\mathrm{NH}_{3}$ is added. When the $\mathrm{O}_{2}$ concentration is less than $5 \%$, NO is removed by the reduction way and $\mathrm{R} 13$ is supposed to be the main reaction. The generated $\mathrm{NO}_{2}$ is removed by the reaction R11. After the addition of $\mathrm{NH}_{3}$, the
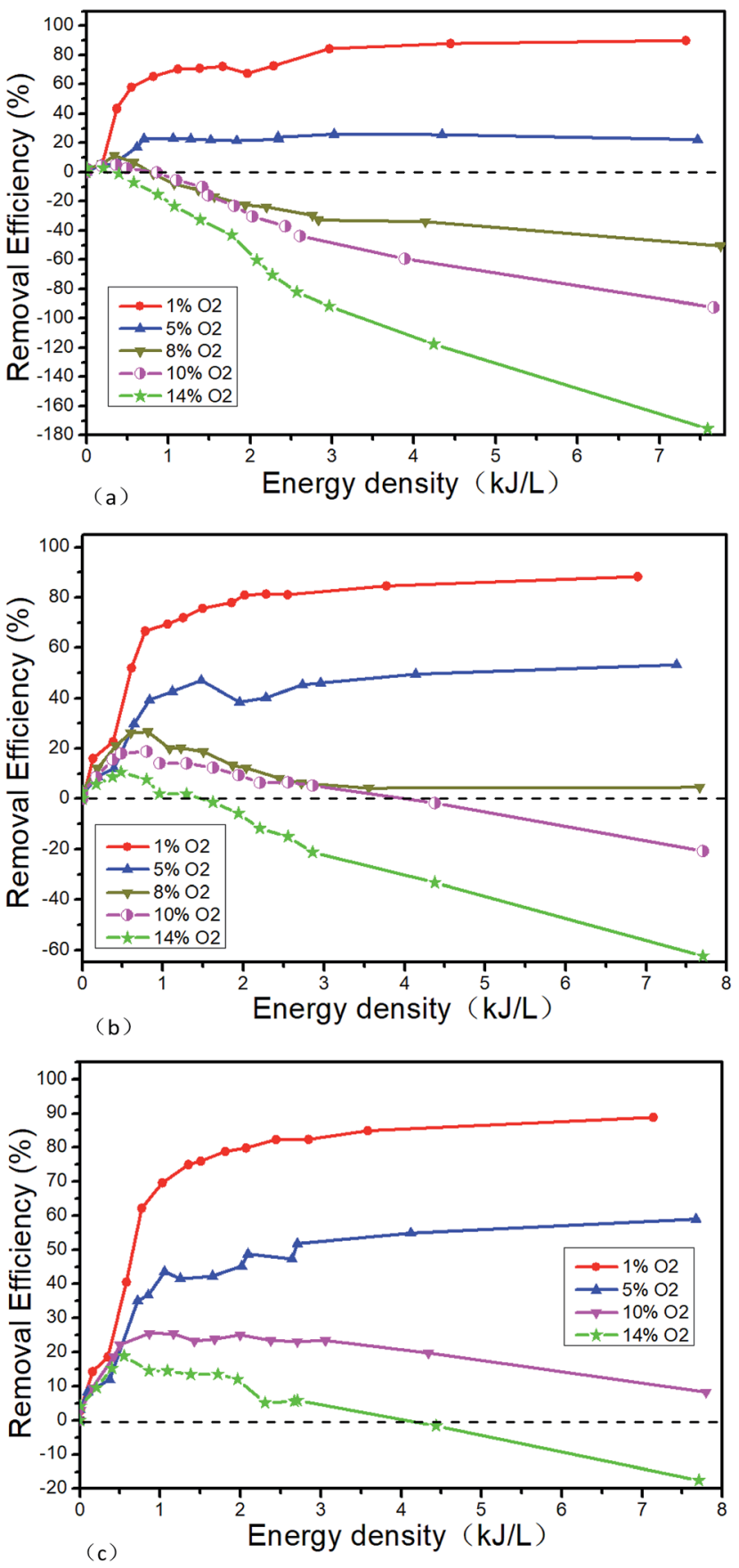

Fig. 12 Denitration performance of NTP in $\mathrm{NO} / \mathrm{NH}_{3} / \mathrm{O}_{2} / \mathrm{N}_{2}$ system, (a) $500 \mu \mathrm{L} \mathrm{L}-1 \mathrm{NO}+500 \mu \mathrm{L} \mathrm{L}^{-1} \mathrm{NH}_{3}+\mathrm{O}_{2}$, (b) $1000 \mu \mathrm{L} \mathrm{L}^{-1} \mathrm{NO}+1000 \mu \mathrm{L}$ $\mathrm{L}^{-1} \mathrm{NH}_{3}+\mathrm{O}_{2}$, (c) $1500 \mu \mathrm{LL} \mathrm{L}^{-1} \mathrm{NO}+1500 \mu \mathrm{L} \mathrm{L}^{-1} \mathrm{NH}_{3}+\mathrm{O}_{2}$.

reactions of R22-R28 mainly take place. At low $\mathrm{O}_{2}$ concentration, the addition of $\mathrm{NH}_{3}$ leads the removal efficiency decreasing. The experimental result may be caused by the fact that in this experimental condition the removal of $\mathrm{NO}_{x}$ is mainly caused by the collision, which breaks the molecular bonds between high-energy particles and molecules generated by NTP. And then the molecular bonds recombine to generate bigger bond energy molecules, such as $\mathrm{N}_{2}$. However, after the addition of $\mathrm{NH}_{3}$, the probability of collision between the high energy 
particles and the NO molecules is lowered, thereby the removal efficiency decreases. When the $\mathrm{O}_{2}$ concentration is greater than $10 \%$, the NTP removal efficiency becomes negative. The reason for this phenomenon may be that the $\mathrm{O}_{2}$ concentration is much higher than NO, and the oxygen-active particles generated by collisions between high-energy particles and $\mathrm{O}_{2}$ molecules are much more, making the reactions $\mathrm{R} 7$ and $\mathrm{R} 8$ more likely to react. Although the $\mathrm{NO}_{x}$ can be decreased after the addition of $\mathrm{NH}_{3}$ at the low ED, the concentration of oxygen-activated particles increases with the ED. And the NO generation rate by oxidation reaction is higher than the removal efficiency by $\mathrm{NH}_{3}$ reduction reaction, which eventually leads to the negative removal efficiency.

Secondly, the experimental results show that the $\mathrm{NO}_{2}$ concentration will be slightly reduced at different $\mathrm{O}_{2}$ concentrations when $\mathrm{NH}_{3}$ is added. Mizuno ${ }^{43}$ believes that NO does not react with $\mathrm{NH}_{3}$ at room temperature, and the conversion of $\mathrm{NO}$ to $\mathrm{NO}_{2}$ is determined by the concentration of $\cdot \mathrm{O}$ instead of the $\mathrm{NH}_{3}$. In the range of room temperature to $150{ }^{\circ} \mathrm{C}, \mathrm{NH}_{3}$ only affects the removal efficiency of $\mathrm{NO}_{2}$ instead of NO.

Based on the findings above, $\mathrm{NH}_{3}$ has little effect on the critical $\mathrm{O}_{2}$ concentration. However, when other initial conditions are constant, the removal efficiency will be greatly improved at the low energy density and further reduced at the high energy density after adding $\mathrm{NH}_{3}$. Therefore, it should be avoided the energy density is too much when $\mathrm{NH}_{3}$ is added, which will result in the oxidation of $\mathrm{NH}_{3}$ and the decrease of the removal efficiency.

$$
\begin{gathered}
\mathrm{e}+\mathrm{NH}_{3} \rightarrow \cdot \mathrm{NH}_{2}+\cdot \mathrm{H} \\
\cdot \mathrm{O}+\mathrm{NH}_{3} \rightarrow \cdot \mathrm{NH}_{2}+\cdot \mathrm{OH} \\
\cdot \mathrm{OH}+\mathrm{NH}_{3} \rightarrow \cdot \mathrm{NH}_{2}+\mathrm{H}_{2} \mathrm{O} \\
\cdot \mathrm{H}+\mathrm{NH}_{3} \rightarrow \cdot \mathrm{NH}_{2}+\mathrm{H}_{2} \\
\cdot \mathrm{NH}_{2}+\mathrm{NO} \rightarrow \mathrm{N}_{2}+\mathrm{H}_{2} \mathrm{O} \\
\cdot \mathrm{NH}_{2}+\mathrm{NO}_{2} \rightarrow \mathrm{N}_{2}+\mathrm{H}_{2} \mathrm{O} \\
\mathrm{NH}_{3}+\mathrm{NO}_{2} \rightarrow \mathrm{N}_{2}+\mathrm{H}_{2} \mathrm{O}
\end{gathered}
$$

\subsection{Effect of $\mathrm{H}_{2} \mathrm{O}$ on NTP denitration performance}

$\mathrm{H}_{2} \mathrm{O}$ is an inevitable combustion product in diesel exhaust. $\mathrm{H}_{2} \mathrm{O}$ can generate a variety of strong oxidizing free radicals in NTP, including $\cdot \mathrm{HO}_{2}, \cdot \mathrm{OH}$ and $\mathrm{H}_{2} \mathrm{O}_{2}$. These strong oxidizing active particles will contribute to the oxidative removal of NO. The possible reactions are R29-R33 ( $\mathrm{M}$ is a third inert body in the reaction system). ${ }^{44}$

Fig. 13 shows the changes of the $\mathrm{NO}_{x}$ concentrations at the outlet when the inlet gases are $1500 \mu \mathrm{L} \mathrm{L}^{-1} \mathrm{NO}+14 \% \mathrm{O}_{2}+5.1 \%$ $\mathrm{H}_{2} \mathrm{O}+\mathrm{N}_{2}$, i.e., $\mathrm{H}_{2} \mathrm{O}$ is added. Fig. 14 shows the denitration performance of $\mathrm{NH}_{3}$ at different $\mathrm{H}_{2} \mathrm{O}$ concentrations in the system of $1500 \mu \mathrm{L} \mathrm{L}^{-1} \mathrm{NO}+14 \% \mathrm{O}_{2}+\mathrm{H}_{2} \mathrm{O}+\mathrm{N}_{2}$, i.e., both $\mathrm{H}_{2} \mathrm{O}$ and $\mathrm{NH}_{3}$ are added. It can be seen from Fig. 13 that $\mathrm{H}_{2} \mathrm{O}$ nearly

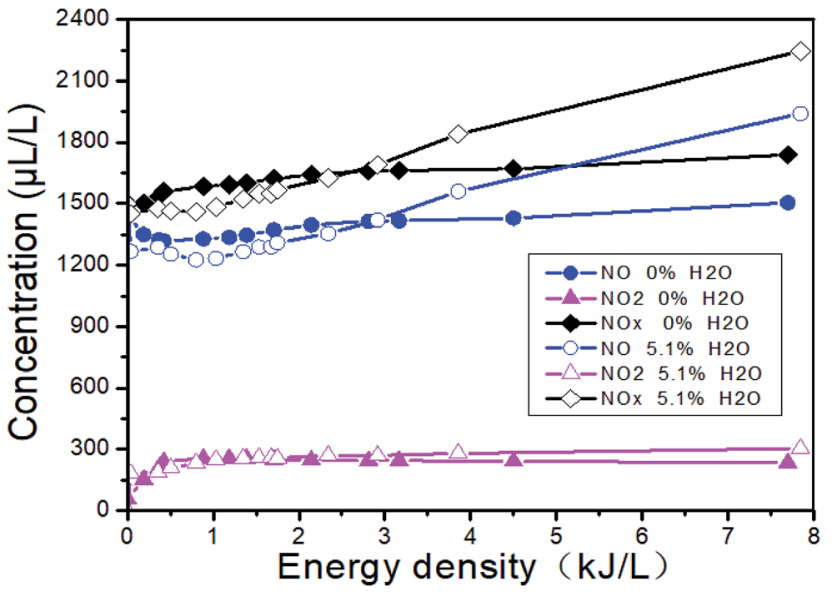

Fig. 13 Effect of $\mathrm{H}_{2} \mathrm{O}$ on the $\mathrm{NO}_{x}$ removal.

has no effect on the concentration of $\mathrm{NO}_{2} \cdot \mathrm{H}_{2} \mathrm{O}$ can reduce the NO concentration a little bit at the low ED and increase the NO concentration at the high ED, which means $\mathrm{H}_{2} \mathrm{O}$ can increase the removal efficiency at the low ED and lower the removal efficiency at the high ED. However, there is no obvious regular pattern between $\mathrm{H}_{2} \mathrm{O}$ concentration and NTP removal efficiency with the increase of the ED (Fig. 14). The reactions mainly consist of R29-R38. When $\mathrm{NH}_{3}$ is added, the removal efficiency increases first and then decreases with the increase of the ED. When both $\mathrm{NH}_{3}$ and $\mathrm{H}_{2} \mathrm{O}$ are present, the removal efficiency of $\mathrm{NO}_{x}$ can be greatly improved.

Fig. 15 shows the changes of NTP removal efficiency at different initial $\mathrm{NO}$ concentrations in the system of $14 \% \mathrm{O}_{2}+$ $5.1 \% \mathrm{H}_{2} \mathrm{O}+\mathrm{NO}+\mathrm{NH}_{3}+\mathrm{N}_{2}$. Whether $\mathrm{NH}_{3}$ is added or not, the removal efficiency of $\mathrm{NO}_{x}$ gradually increases with the initial NO concentration. At constant initial NO concentration, the removal efficiency increases first and then decreases with the increase of the ED. This conclusion has been shown in Section 3.5. The addition of $\mathrm{NH}_{3}$ will contribute to the increase of removal efficiency in the whole $\mathrm{ED}$ range in the system of $1500 \mu \mathrm{L} \mathrm{L}^{-1} \mathrm{NO}+14 \% \mathrm{O}_{2}+5.1 \% \mathrm{H}_{2} \mathrm{O}+\mathrm{NH}_{3}+\mathrm{N}_{2}$,

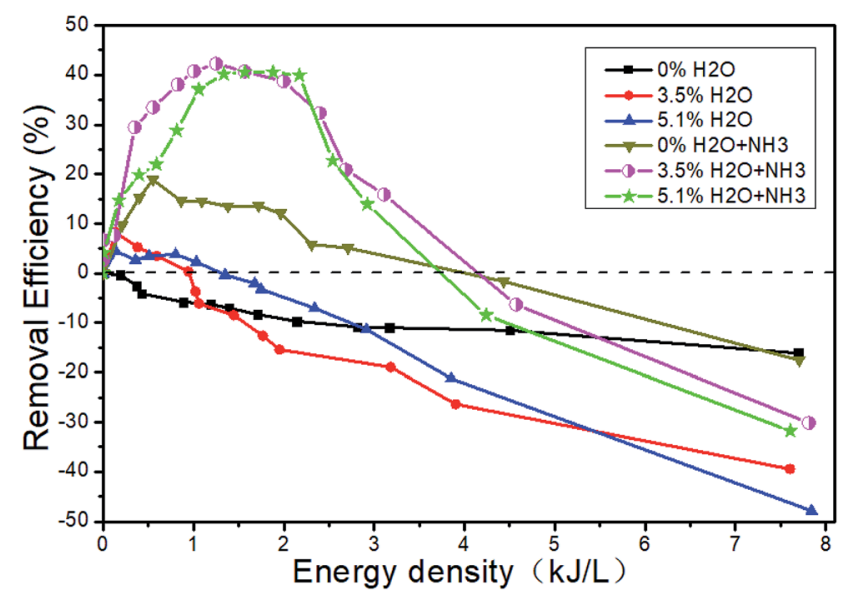

Fig. 14 Effect of $\mathrm{H}_{2} \mathrm{O}$ and $\mathrm{NH}_{3}$ on the removal efficiency. 


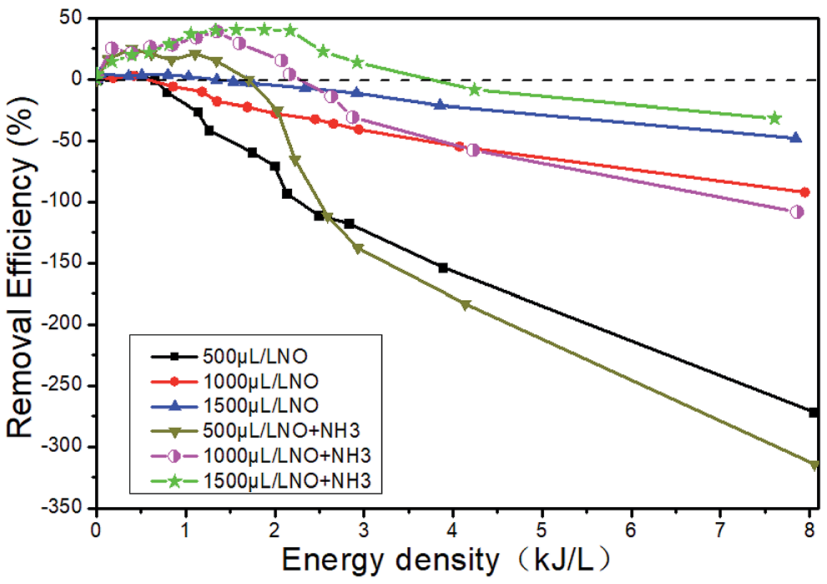

Fig. 15 Effect of $\mathrm{H}_{2} \mathrm{O}$ on NTP denitration performance at different initial NO concentrations.

and the removal efficiency is up to $40.6 \%$ when the ED is 1.57 $\mathrm{kJ} \mathrm{L}^{-1}$.

In general, $\mathrm{H}_{2} \mathrm{O}$ can increase the NTP removal efficiency at the low ED and reduce the removal efficiency at the high ED. When $\mathrm{H}_{2} \mathrm{O}$ and $\mathrm{NH}_{3}$ coexist, the NTP removal efficiency is greatly improved. Therefore, the system consists of the following reactions:

$$
\begin{gathered}
\mathrm{e}+\mathrm{H}_{2} \mathrm{O} \rightarrow \mathrm{e}+\cdot \mathrm{H}+\cdot \mathrm{OH} \\
\mathrm{O}\left({ }^{1} \mathrm{D}\right)+\mathrm{H}_{2} \mathrm{O} \rightarrow \cdot \mathrm{OH}+\cdot \mathrm{OH} \\
\cdot \mathrm{OH}+\cdot \mathrm{OH}+\mathrm{M} \rightarrow \mathrm{H}_{2} \mathrm{O}_{2}+\mathrm{M} \\
\mathrm{O}\left({ }^{3} \mathrm{P}\right)+\cdot \mathrm{OH} \rightarrow \mathrm{O}_{2}+\cdot \mathrm{H} \\
\mathrm{O}_{2}+\cdot \mathrm{H} \rightarrow \cdot \mathrm{HO}_{2} \\
\mathrm{NO}+2 \cdot \mathrm{OH} \rightarrow \mathrm{NO}_{2}+\mathrm{H}_{2} \mathrm{O} \\
\mathrm{NO}+\cdot \mathrm{HO} \mathrm{NO}_{2}+\cdot \mathrm{NH}_{2} \\
\mathrm{NO}+\cdot \mathrm{OH} \rightarrow \mathrm{HNO}_{2} \\
\mathrm{HNO}_{2}+\cdot \mathrm{OH} \rightarrow \mathrm{NO}_{2}+\mathrm{H}_{2} \mathrm{O} \\
\mathrm{NO}_{2}+\cdot \mathrm{OH} \rightarrow \mathrm{HNO}_{3}
\end{gathered}
$$

\subsection{Effect of $\mathrm{CO}_{2}$ on NTP denitration performance}

$\mathrm{CO}_{2}$ is also an inevitable combustion product in diesel exhaust, and most researchers have not explored the effects of $\mathrm{CO}_{2}$ on the NTP denitration. Therefore, in this section we investigate the impact of $\mathrm{CO}_{2}$ in the NTP system for different initial NO concentrations and the presence of $\mathrm{NH}_{3}$.

The effects of $4.5 \% \mathrm{CO}_{2}$ on the DBD outlet gas concentration in the system of $1500 \mu \mathrm{L} \mathrm{L}^{-1} \mathrm{NO}+14 \% \mathrm{O}_{2}+5.1 \% \mathrm{H}_{2} \mathrm{O}+\mathrm{N}_{2}$ are shown in Fig. 16(a). The effect of $4.5 \% \mathrm{CO}_{2}$ on the NTP removal efficiency at different initial NO concentration in $14 \% \mathrm{O}_{2}+5.1 \%$
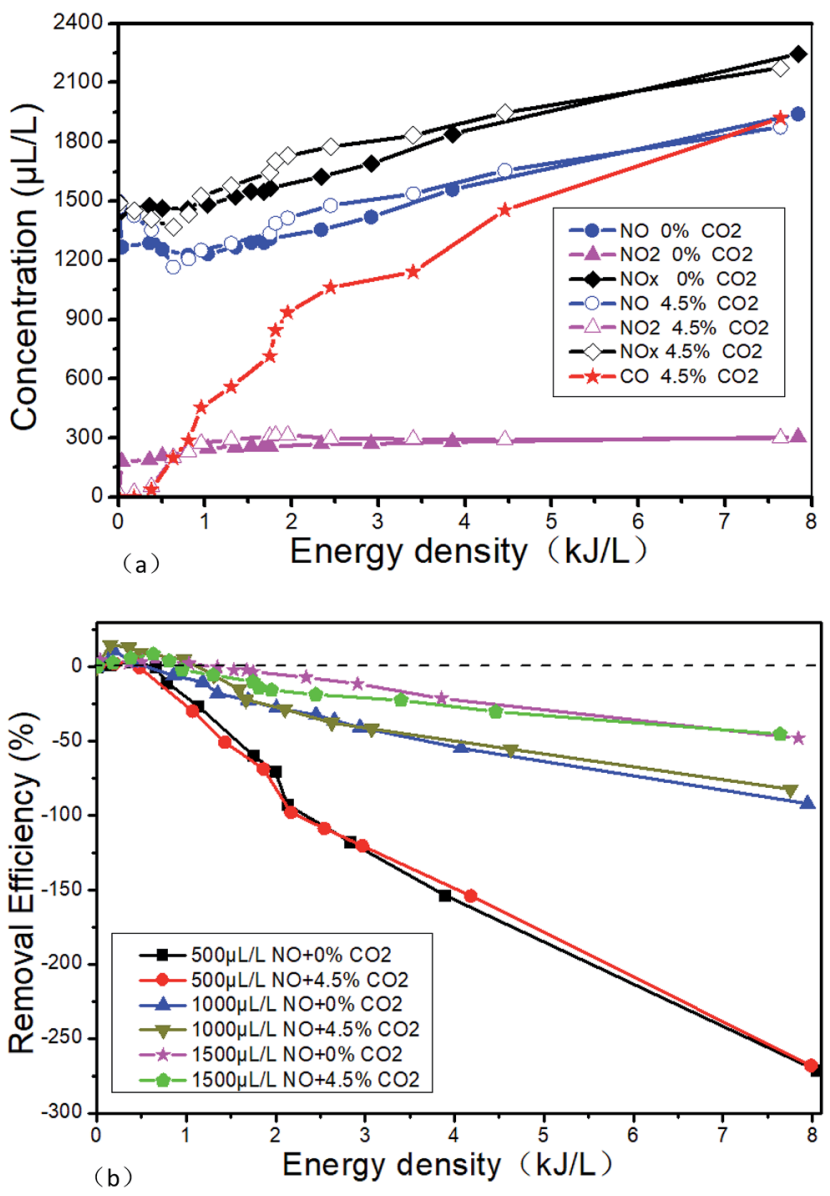

Fig. 16 Effects of $\mathrm{CO}_{2}$ on the NTP denitration performance, (a) effects of $\mathrm{CO}_{2}$ on DBD outlet gas concentration in the system of $1500 \mu \mathrm{L} \mathrm{L}^{-1}$ $\mathrm{NO}+14 \% \mathrm{O}_{2}+5.1 \% \mathrm{H}_{2} \mathrm{O}+76.2 \% \mathrm{~N}_{2}$. (b) Effects of $\mathrm{CO}_{2}$ on the NTP removal efficiency at different initial $\mathrm{NO}$ concentration in $14 \% \mathrm{O}_{2}+$ $5.1 \% \mathrm{H}_{2} \mathrm{O}+76.2 \% \mathrm{~N}_{2}+\mathrm{NO}$.

$\mathrm{H}_{2} \mathrm{O}+\mathrm{N}_{2}+\mathrm{NO}$ is shown in Fig. 16(b). It can be seen from Fig. 16(a) that $\mathrm{CO}_{2}$ almost has no effect on the concentration of $\mathrm{NO}$ and $\mathrm{NO}_{2}$ at the DBD outlet. But when $4.5 \% \mathrm{CO}_{2}$ is added, a certain concentration of $\mathrm{CO}$ will be produced, and the outlet $\mathrm{CO}$ concentration will gradually increase with the ED. When the $\mathrm{ED}$ is $7.64 \mathrm{~kJ} \mathrm{~L}^{-1}$, the CO concentration is up to $1920 \mu \mathrm{L} \mathrm{L}^{-1}$. The possible reactions are $\mathrm{R} 39-\mathrm{R} 43$. And $\mathrm{R} 40$ is the main reaction because $\mathrm{CO}_{2}$ concentration is much higher than the $\mathrm{CO}$. It can be seen from Fig. 16(b) that $\mathrm{CO}_{2}$ basically does not have any influence on the NTP removal efficiency at different initial NO concentrations.

The changes of NTP removal efficiency at different initial NO concentrations are shown in Fig. 17 when $\mathrm{NH}_{3}$ is added in the system of $14 \% \mathrm{O}_{2}+5.1 \% \mathrm{H}_{2} \mathrm{O}+4.5 \% \mathrm{CO}_{2}+76.2 \% \mathrm{~N}_{2}+\mathrm{NO}$. The $\mathrm{CO}$ concentration in the outlet increases with the $\mathrm{ED}$ instead of the initial NO concentration. The NTP removal efficiency increases significantly when $\mathrm{NH}_{3}$ is added. However, $\mathrm{CO}_{2}$ has no effect on the NTP removal efficiency in the presence of $\mathrm{NH}_{3}$ when compared with Fig. 15. In addition, we opened the DBD reactor after the experiment of adding $\mathrm{CO}_{2}$, and a layer of black carbon was observed on the surface of high-pressure copper 


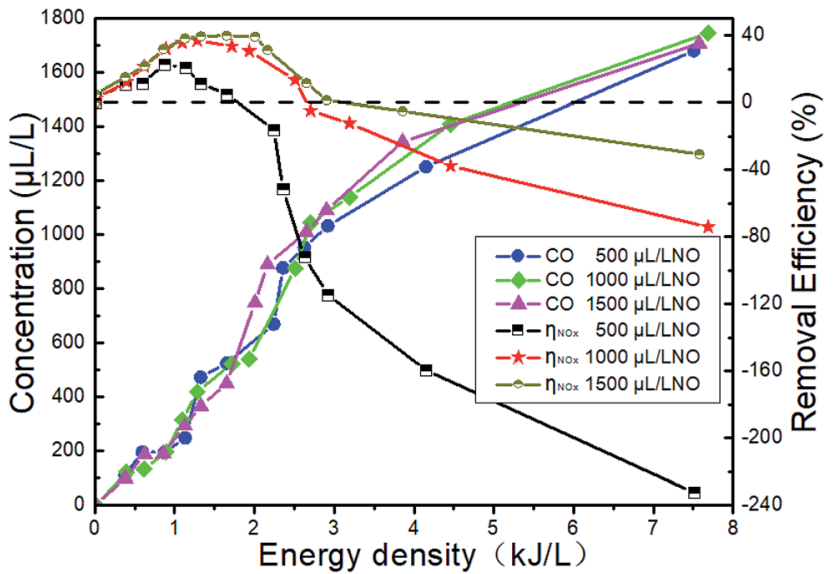

Fig. 17 Effect of $\mathrm{CO}_{2}$ on NTP removal efficiency with the presence of $\mathrm{NH}_{3}$.

rod. This may be due to the further decomposition of CO, which means reaction $\mathrm{R} 44$ occurred.

In summary, $\mathrm{CO}_{2}$ nearly has no effect on the removal efficiency of $\mathrm{NO}_{x}$ under different experimental conditions. But $\mathrm{CO}$ will be detected in the outlet and black carbon will be generated on the surface of high-voltage electrode after adding $\mathrm{CO}_{2}$, and the $\mathrm{CO}$ concentration will gradually increase with the ED.

$$
\begin{gathered}
\mathrm{e}+\mathrm{CO}_{2} \rightarrow \mathrm{e}+\cdot \mathrm{O}+\mathrm{CO} \\
\mathrm{CO}+\cdot \mathrm{O} \rightarrow \mathrm{CO}_{2} \\
\mathrm{CO}+2 \cdot \mathrm{OH} \rightarrow \mathrm{CO}_{2}+\mathrm{H}_{2} \mathrm{O} \\
\mathrm{CO}+\cdot \mathrm{HO}_{2} \rightarrow \mathrm{CO}_{2}+\cdot \mathrm{OH} \\
\mathrm{e}+\mathrm{CO} \rightarrow \mathrm{O}+\cdot \mathrm{O}+\mathrm{C}
\end{gathered}
$$

\section{Reaction mechanism of $\mathrm{NO}_{x}$ and application prospect of NTP}

\subsection{Reaction mechanism of $\mathrm{NO}_{x}$ in NTP}

When the inlet gases are $\mathrm{N}_{2}, \mathrm{O}_{2}, \mathrm{CO}_{2}, \mathrm{H}_{2} \mathrm{O}$, NO and $\mathrm{NH}_{3}$, NTP denitration can be roughly divided into three stages. ${ }^{16,22,40,45}$

(1) The first stage is the discharge. At this stage gas molecules are mainly bombarded by high-energy electrons. It breaks the molecular covalent bonds, changes the gas molecules into free radicals and excites some decomposed atoms to the unstable excited state. The following reactions mainly take place at this stage: R1-R4, R14 and R15, R22, R29, R39 and R44.

(2) The second stage is the post-discharge. At this stage the excited-state atoms generated in the first stage collide with the gas molecules to generate secondary radicals. Then the radicals collide with other particles leading to quench or new radicals' generation. The reactions are mainly R5 and R6, R16, R23-R25, R30-R33.

(3) The third stage is that the free radicals react with $\mathrm{NO}_{x}$. The reactions mainly include R7-R13, R17-R21, R26-R28, R34$\mathrm{R} 38$. The reactions of free radicals with CO mainly include R40R43.

In general, under our experimental conditions, the reaction mechanism of diesel engine exhaust in the NTP system is shown in Fig. 18. It mainly consists of two parts. The first is that gas molecules generate various free radicals under the bombardment of high-energy electrons. The second is the radicals react with other particles. The reaction process of $\mathrm{NO}_{x}$ with free radicals is described in the right of Fig. 18. Other researchers ${ }^{\mathbf{1 6 2 2 , 4 0 , 4 5}}$ get the similar results with us. While our experimental results show that $\mathrm{CO}_{2}$ has little effect on the removal efficiency of $\mathrm{NO}_{x} \cdot \mathrm{CO}_{2}$ is converted to $\mathrm{CO}$ and even further converted to black carbon. Therefore, the reaction process of $\mathrm{CO}_{2}$ in NTP is separately listed in the left of Fig. 18.

\subsection{Analysis of NTP application prospect}

As NO can be removed by oxidation or reduction, when the $\mathrm{O}_{2}$ concentration is low, NO is mainly removed by the reduction route. When the $\mathrm{O}_{2}$ concentration is high, many strong oxidative constituents are generated such as $\cdot \mathrm{OH}, \cdot \mathrm{O}$ and $\mathrm{O}_{3}$. And then the $\mathrm{NO}$ is oxidized to $\mathrm{NO}_{2}$. But $\mathrm{N}_{2}$ will be converted to $\mathrm{NO}_{x}$ at high $\mathrm{O}_{2}$ concentration and high energy density, causing the NTP removal efficiency to become negative. Although it is beneficial to the NTP removal efficiency improvement when the initial NO concentration is higher, it is difficult to further improve removal efficiency only by NTP technology because of

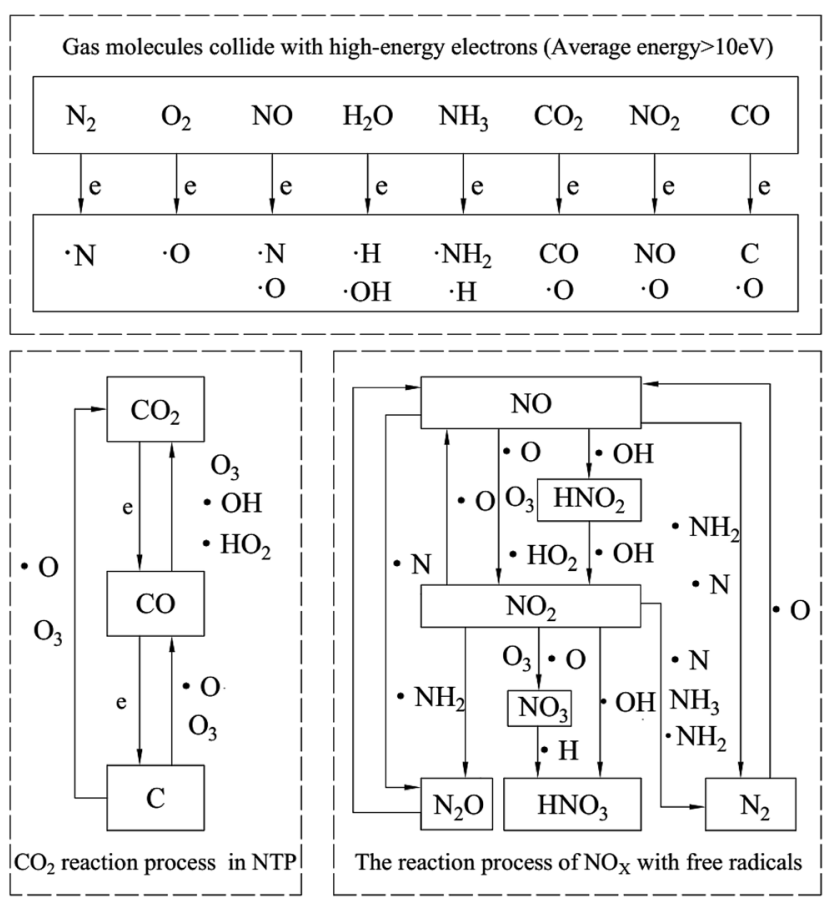

Fig. 18 Reaction mechanism of diesel engine exhaust gas in NTP system. 
the high $\mathrm{O}_{2}$ concentration in the marine diesel exhaust. In this paper, the highest removal efficiency is only $8.6 \%$ at $0.8 \mathrm{~kJ} \mathrm{~L}^{-1}$ energy density when inlet gases are $1500 \mu \mathrm{L} \mathrm{L}^{-1} \mathrm{NO}+14 \% \mathrm{O}_{2}+$ $5.1 \% \mathrm{H}_{2} \mathrm{O}+4.5 \% \mathrm{CO}_{2}+76.2 \% \mathrm{~N}_{2}$. Chmielewski ${ }^{12}$ simulated the diesel engine exhaust conditions when burning heavy oil, and the removal efficiency obtained was also very low. Therefore, in order to achieve high-efficiency $\mathrm{NO}_{x}$ removal at high $\mathrm{O}_{2}$ concentration, it is necessary to combine NTP denitration technology with other methods. The possible methods include the following:

(1) Adding reducing gas, such as $\mathrm{H}_{2},{ }^{46} \mathrm{NH}_{3}$ (ref. 11, 21 and 47-49) and $\mathrm{HC}^{50-52}$ (including $\mathrm{CH}_{4}, \mathrm{C}_{2} \mathrm{H}_{2}, \mathrm{C}_{2} \mathrm{H}_{4}, \mathrm{C}_{3} \mathrm{H}_{6}$, etc.). In this paper, the highest removal efficiency of $40.6 \%$ is obtained at the energy density of $1.65 \mathrm{~kJ} \mathrm{~L}^{-1}$ when $\mathrm{NH}_{3}$ is added.

(2) Combining NTP with the denitration catalysts. ${ }^{15,21,49,51,53-56}$ The catalysts commonly used include molecular sieves, activated carbon and metal oxides. For example, we can combine NTP with traditional vanadium-based SCR catalyst. Because NTP can convert NO to $\mathrm{NO}_{2}$, which means increasing $\mathrm{NO}_{2} / \mathrm{NO}_{x}$ ratio, it is beneficial to increase the reaction rate of SCR. ${ }^{57}$ The removal efficiency is generally above $90 \%$ in this way, but it is also necessary to add reducing gas.

(3) Combining NTP with wet scrubbing technology. ${ }^{58-60}$ This technology has matured on ships today. NTP can oxidize NO to $\mathrm{NO}_{2}$ which is more soluble in water. Chmielewski ${ }^{11}$ obtained the removal efficiency of $49 \%$ by combining NTP with wet scrubbing. And Yang ${ }^{61}$ got the removal efficiency of more than $60 \%$ by combing electrolytic seawater with wet scrubbing. However, in general, the removal efficiency is still much lower than the traditional methods such as SCR technology.

A major problem for NTP industrial applications is that energy consumption of NTP is very large. Improving the energy utilization rate can be solved by optimizing the structure of the DBD reactor and matching the reactor with the power source.

\section{Conclusions}

A non-thermal plasma denitration system based on simulated diesel engine exhaust was set up in this paper. The NTP was generated by dielectric barrier discharge reactor. The NO removal performance by NTP under different $\mathrm{O}_{2}, \mathrm{H}_{2} \mathrm{O}, \mathrm{CO}_{2}$, NO, $\mathrm{NH}_{3}$ concentrations and energy densities conditions were studied. The reaction mechanism of $\mathrm{NO}_{x}$ in NTP system was proposed. The application prospect of NTP technology was analyzed. In the end we get the following conclusions:

(1) For the experimental system, the power source efficiency gradually increases with the input voltage. When the input voltage is greater than $60 \mathrm{~V}$, the power supply efficiency is basically maintained above $80 \%$.

(2) NO concentration increases gradually with the $\mathrm{O}_{2}$ concentration and the ED in the $\mathrm{N}_{2} / \mathrm{O}_{2}$ system. When the $\mathrm{O}_{2}$ concentration is $14 \%$ and the $\mathrm{ED}$ is $7.3 \mathrm{~kJ} \mathrm{~L}^{-1}$, the concentration of NO is up to $1018 \mu \mathrm{L} \mathrm{L}^{-1}$. The amount of $\mathrm{NO}_{2}$ increases and then stabilizes with the ED. When the $\mathrm{O}_{2}$ concentration is $5 \%$ and the $\mathrm{ED}$ is $0.9 \mathrm{~kJ} \mathrm{~L}^{-1}$, the concentration of $\mathrm{NO}_{2}$ is up to 380 $\mu \mathrm{L} \mathrm{L}^{-1}$. Therefore, a certain concentration of $\mathrm{NO}_{x}$ will be generated when introducing NTP in the air.

(3) NTP has a high removal efficiency for $\mathrm{NO} / \mathrm{N}_{2}$ system. When low concentration $\mathrm{O}_{2}$ exists, NTP removal efficiency is above $90 \%$. And NO is mainly removed by the reduction route. NTP will have no denitration performance at high concentration of $\mathrm{O}_{2}$. However, $\mathrm{NH}_{3}$ can inhibit the formation of $\mathrm{NO}_{x}$ and improve the removal efficiency. At low $\mathrm{O}_{2}$ concentration, the removal efficiency of $\mathrm{NO}_{x}$ gradually increases with the ED; at high $\mathrm{O}_{2}$ concentration, the removal efficiency becomes negative. And the higher the $\mathrm{ED}$, the more $\mathrm{NO}_{x}$ will generate. Therefore, the $\mathrm{O}_{2}$ concentration plays a decisive role in NTP denitration performance. And the critical $\mathrm{O}_{2}$ concentration increases with the initial NO concentration.

(4) Under typical diesel engine exhaust condition, $\mathrm{H}_{2} \mathrm{O}$ has little effect on $\mathrm{NO}_{2}$ when $\mathrm{NH}_{3}$ is not added, but it can increase NO removal efficiency at the low ED and the excessive ED causes the increasement of NO at the outlet. The highest removal efficiency of $4.5 \%$ can be obtained in the system of $1500 \mu \mathrm{L} \mathrm{L}^{-1}$ $\mathrm{NO}+14 \% \mathrm{O}_{2}+5.1 \% \mathrm{H}_{2} \mathrm{O}+\mathrm{N}_{2}$. The highest removal efficiency of $18.9 \%$ can be obtained in the system of $1500 \mu \mathrm{L} \mathrm{L}^{-1} \mathrm{NO}+1500$ $\mu \mathrm{L} \mathrm{L}^{-1} \mathrm{NH}_{3}+14 \% \mathrm{O}_{2}+\mathrm{N}_{2}$. However, when $\mathrm{H}_{2} \mathrm{O}$ and $\mathrm{NH}_{3}$ are added, the removal efficiency is up to $40.6 \%$ in the system of $1500 \mu \mathrm{L} \mathrm{L}^{-1} \mathrm{NO}+1500 \mu \mathrm{L} \mathrm{L}^{-1} \mathrm{NH}_{3}+5.1 \% \mathrm{H}_{2} \mathrm{O}+14 \% \mathrm{O}_{2}+\mathrm{N}_{2}$ because of the synergistic effect.

(5) $\mathrm{CO}_{2}$ nearly has no effect on the removal efficiency of $\mathrm{NO}_{x}$, but the concentration of $\mathrm{CO}$ will increase gradually with the ED. When the ED is $7.64 \mathrm{~kJ} \mathrm{~L}^{-1}$, the CO concentration will up to $1920 \mu \mathrm{L} \mathrm{L}^{-1}$. The reaction process of $\mathrm{CO}_{2}$ is added in the reaction mechanism of diesel engine exhaust in NTP system.

(6) Because of the high concentration of $\mathrm{O}_{2}$ in the marine diesel engine exhaust, in order to further improve the removal efficiency of $\mathrm{NO}_{x}$, it is necessary to add reducing gas to the NTP reactor, or combine the NTP technology with SCR catalysts or other technologies such as wet scrubbing.

\section{Conflicts of interest}

There are no conflicts to declare.

\section{Acknowledgements}

This work was supported by National Natural Science Foundation of China (51876019), Innovation Talent Support Program of Liaoning Province (LR2017048), and Transportation Industry High-Level Talent Training Program.

\section{Notes and references}

1 IMO, MARPOL Annex VI and NTC 2008 with Guidelines for Implementation, International Maritime Organization, London, UK, 2013 edn, 2013.

2 F. Di Natale, C. Carotenutoa, L. D'Addioa, A. Lanciaa, T. Antesb, M. Szudygab, A. Jaworekc, D. Gregoryd, M. Jacksone and P. Volpef, Chem. Eng., 2013, 32, 361-366.

3 P. Fang, X. Chen, Z. Tang, J. Huang and W. Zeng, Chem. Ind. Eng. Prog., 2017, 36, 1067-1076. 
4 J. Huang, J. He, T. Li, S. Yu, Y. Shi and D. Fan, Transactions on Intelligent Welding Manufacturing, Springer, 2018.

5 B. Zhou, X. Qian, M. Li, J. Ma, L. Liu, C. Hu, Z. Xu and X. J. J. o. N. R. Jiao, J. Nanopart. Res., 2015, 17, 130.

6 M. Yue, B. Zhou, K. Jiao, X. Qian, Z. Xu, K. Teng, L. Zhao, J. Wang and Y. J. A. S. S. Jiao, Appl. Surf. Sci., 2015, 327, 93-99.

7 C. Zhang, L. Liu, Z. Xu, H. Lv, N. Wu, B. Zhou, W. Mai, L. Zhao, X. Tian and X. J. P. C. Guo, Polym. Compos., 2018, 39, E1262-E1268.

8 S. Ma, Y. Zhao, J. Yang, S. Zhang, J. Zhang and C. Zheng, Renewable Sustainable Energy Rev., 2017, 67, 791-810.

9 W. Balachandran, N. Manivannan, R. Beleca, M. F. Abbod, D. Brennen, N. S. Alozie and L. C. Ganippa, IEEE Trans. Ind. Appl., 2016, 52, 2496-2505.

10 T. Kuwahara, H. Nakaguchi, T. Kuroki and M. Okubo, J. Hazard. Mater., 2016, 308, 216-224.

11 B. M. Penetrante and S. E. Schultheis, Non-thermal plasma techniques for pollution control: part b: electron beam and electrical discharge processing, Springer Science \& Business Media, 2013.

12 A. G. Chmielewski, E. Zwolińska, J. Licki, Y. Sun, Z. Zimek and S. Bułka, Radiat. Phys. Chem., 2018, 144, 1-7.

13 Y.-j. Jin, J. Xin, J.-j. Yao, B. Zhang, D. Song and R.-x. Shi, J. Fuel Chem. Technol., 2011, 39, 460-464.

14 Z. Wei, G. Zeng, Z. Xie, C. Ma, X. Liu, J. Sun and L. Liu, Fuel, 2011, 90, 1599-1603.

15 R. McAdams, P. Beech, R. Gillespie, C. Guy, S. Jones, T. Liddell, R. Morgan, J. Shawcross, D. Weeks and D. Hughes, Non-thermal plasma based technologies for the after-treatment of automotive exhaust particulates and marine diesel exhaust NOx,Accentus plc, Warship Support Agency J Oesterle; GmbH\& Co. KG, US, 2003.

16 Y. S. Mok and I.-S. Nam, Chem. Eng. J., 2002, 85, 87-97.

17 A. Mizuno, J. S. Clements and R. H. Davis, IEEE Trans. Ind. Appl., 1986, 516-552.

18 R. Brandenburg, H. Wagner, A. Morozov and K. Kozlov, J. Phys. D: Appl. Phys., 2005, 38, 1649.

19 T. Wang, B.-M. Sun, H.-P. Xiao, J.-y. Zeng, E.-p. Duan, J. Xin and C. Li, Plasma Chem. Plasma Process., 2012, 32, 11891201.

20 K. Yukimura, K. Kawamura, T. Hiramatsu, H. Murakami, S. Kambara, H. Moritomi and T. Yamashita, Thin Solid Films, 2007, 515, 4278-4282.

21 M. Cha, Y. Song, J. Lee and S. Kim, Int. J. Environ. Sci. Technol., 2007, 1, 28-33.

22 Q. Yu, Y. Gao, X. Tang, H. Yi, R. Zhang, S. Zhao, F. Gao and Y. Zhou, Catal. Commun., 2018, 110, 18-22.

23 B. Li, Marine Diesel Engine, Dalian Maritime University Press, Dalian, China, 2008.

24 G. B. Zhao, S. J. Garikipati, X. Hu, M. D. Argyle and M. Radosz, AlChE J., 2005, 51, 1800-1812.

25 Y. Zhou, Z. Zhong, Z. Fu and D. Zhong, East China Electric Power, 2012, 7, 1217-1221.

26 J. Zhang, Y. Zhou, Z. Zhong, X. Jiang and G. Piao, J. Southeast Univ., 2014, 44, 1194-1199.
27 K. Aritoshi, M. Fujiwara and M. Ishida, Jpn. J. Appl. Phys., 2002, 41, 3936.

28 X.-j. Liang, Z.-p. Zhong, B.-s. Jin, H.-g. Wei and H.-k. Guo, J. Energy Power Eng., 2009, 5, 016.

29 L. Lu, Z. Qiang and G. Lili, Industrial Catalysis, 2017, 12, 001.

30 C. Ren, Master's thesis, Beijing University of Chemical Technology, Beijing, China, 2011.

$31 \mathrm{X}$. Wang, Master's thesis, Beijing University of Chemical Technology, Beijing, China, 2012.

32 L. A. Rosenthal and D. A. Davis, IEEE Trans. Ind. Appl., 1975, 328-335.

33 D. Wang, Master's thesis, North China Electric Power University, Beijing, China, 2014.

$34 \mathrm{H}$. Sun, Master thesis, North China Electric Power University, Beijing, China, 2009.

35 J. T. Herron, J. Phys. Chem. Ref. Data, 1999, 28, 1453-1483.

36 A. Fernandez, A. Goumri and A. Fontijn, J. Phys. Chem. A, 1998, 102, 168-172.

37 J. T. Herron and D. S. Green, Plasma Chem. Plasma Process., 2001, 21, 459-481.

38 R. Atkinson, D. Baulch, R. Cox, R. Hampson Jr, J. Kerr, M. Rossi and J. Troe, J. Phys. Chem. Ref. Data, 1997, 26, 1329-1499.

39 R. Ji, W. Xu, J. Wang, C. Yan and T. Zhu, J. Chem. Eng., 2018, 69, 2353-2363.

40 W. Liang, J. Li and T. Zhu, Air pollution control technology and application of low temperature plasma, Chemical Industry Press, Beijing, China, 2016.

41 O. Tokunaga and N. Suzuki, Radiat. Phys. Chem., 1984, 24, 145-165.

42 C. Xie, Master's thesis, Wuhan Textile University, Wuhan, China, 2015.

43 A. Mizuno, IEEE Trans. Dielectr. Electr. Insul., 2000, 7, 615624.

44 S. Ding, Q. Yu, Y. Zhang, Y. Liu, C. Xie and G. Yu, J. Adv. Oxid. Technol., 2015, 18, 114-122.

45 L. Yin, Master's thesis, Jiangsu University, Zhenjiang, China, 2016.

46 R. Gholami, C. E. Stere, A. Goguet and C. Hardacre, Philos. Trans. R. Soc., A, 2018, 376, 20170054.

47 M.-F. Hsieh and J. Wang, Control Eng. Pract., 2011, 19, 409422.

48 S. Brandenberger, O. Kröcher, A. Tissler and R. Althoff, Appl. Catal., B, 2010, 95, 348-357.

49 T. Wang, X. Zhang, J. Liu, H. Liu, Y. Wang and B. Sun, Appl. Therm. Eng., 2018, 130, 1224-1232.

50 H. Wang, Y. Cao, Z. Chen, Q. Yu and S. Wu, Fuel, 2018, 224, 323-330.

51 T. Wang, H. Liu, X. Zhang, Y. Guo, Y. Zhang, Y. Wang and B. Sun, Fuel Process. Technol., 2017, 158, 199-205.

52 D. H. Lee, K.-T. Kim, H. S. Kang, Y.-H. Song and J. E. Park, Environ. Sci. Technol., 2013, 47, 10964-10970.

53 R. McAdams, P. Beech and J. Shawcross, Plasma Chem. Plasma Process., 2008, 28, 159-171.

54 S. Bröer and T. Hammer, Appl. Catal., B, 2000, 28, 101-111. 55 J. Chen, Y. Chen, M. Zhou, Z. Huang, J. Gao, Z. Ma, J. Chen and X. Tang, Environ. Sci. Technol., 2016, 51, 473-478. 
56 Q. Yu, H. Wang, T. Liu, L. Xiao, X. Jiang and X. Zheng, Environ. Sci. Technol., 2012, 46, 2337-2344.

57 S.-Z. Bai, G.-H. Wang, Y. Liu, L. Sun and G.-X. Li, Fresenius Environ. Bull., 2017, 26, 1359-1364.

58 T. Kuroki, S. Nishii, T. Kuwahara and M. Okubo, J. 61 S. Yang, X. Pan, Z. Han, D. Zhao, B. Liu, D. Zheng and Z. Yan, Electrostat., 2017, 87, 86-92.
59 W. Yu, Master's thesis, Wuhan Textile University, Wuhan, China, 2013.

60 S. Yang, Z. Han, X. Pan, Z. Yan and J. Yu, RSC Adv., 2016, 6, 114623-114631.

Chem. Eng. J., 2018, 331, 8-15. 